\title{
Analogies Between Language and Painting in the Philosophy of Philip Melanchthon
}

\section{HANNA SZABELSKA}

Cet article propose une étude des transformations des relations entre l'image et la pensée dans l'épistémologie de Melanchton, et les confronte avec la conception de ce dernier des Topiques en tant que structure de la réalité et explication des arts d'imitation. En examinant l'iconicité linguistique de Melanchton, l'auteur soutient que ses opinions ont évolué vers une forme de métaphysique du langage, dont certaines caractéristiques ont échappé à l'attention des chercheurs. Traditionnellement, la conception qu'avait Melanchton du langage était aristotélicienne. Il a néanmoins conçu de profondes structures sémantiques, sous-jacentes au langage et modifiables dans le temps ; ce qui le différencie nettement de Guillaume d'Ockham qui concevait le langage mental comme universel. Pour Melanchton, les idées et les mots sont étroitement reliés, dans la mesure toutefois où l'on considère leur fonction créative au sein du processus cognitif. La primauté épistémologique du langage ne signifie par pour autant que les idées basées sur les données fournies par les sens étaient éliminées du processus cognitif. Le langage façonne ces structures profondes, dont font partie ces idées basées sur les sens, en intégrant des idées transmises par la tradition philosophique classique.

$\mathrm{T}$ he purpose of the present study is to investigate the epistemological roots of the phenomenon of iconicity in Melanchthon's works. I shall present them against the background of the most recent research on the function of image and its analogies with picture in Aristotle's theory of language. By contrasting Aristotelian and Melanchthonian solutions (which are otherwise closely related) we can trace the modification of the relationship between image and thought, which has been disregarded by scholars of Melanchthon's theological philosophy. My intention is to argue that this modification is top- 
ically dependent, i.e. linked to the dialectical Topics codified in the manuals Compendiaria dialectices ratio (1520), De dialectica libri quattuor (1528), and Erotemata dialectices (1547), and is symptomatic of Melanchthon's evolution towards some kind of metaphysics of language.

Let us begin with an analysis of one characteristic passage, where the analogy between speech and picture is placed against the backdrop of their relationship to notions. This passage stems from one of Melanchthon's declamations, entitled Encomion eloquentiae (1523):

\begin{abstract}
And just as in bodies being shaped, there is certainly this elegance, where all the members do harmonize with each other thanks to a right proportion, and if you do something otherwise, it will become monstrous; so if you deform the natural shape of speech through a new composition, you will make it totally monstrous and ridiculous. In truth, will a painter imitate a body properly if he moves his brush without any skill, if a hand is thoughtlessly guided and lines are not drawn skillfully? In this way, you could not show also the thought of your soul to others unless you employed proper and clear words, an appropriate composition of words, a right order of sentences. For we represent the thought of the soul with speech as we do bodies with colours. Because of it, a certain image, which discerns so to say the faces of sentences, must be shaped skillfully through speech. ${ }^{1}$
\end{abstract}

As we can see, Melanchthon employed the congeries of analogically constructed comparisons of painting and speech (speech understood as the subject of rhetoric, enriched by the competence of grammar). In so doing, he remained in accordance with the convention of declamations belonging to genus demonstrativum. The point of departure for interpreting the interdependence between picture and language should therefore be Melanchthon's rhetorical conceptions that allow one to unravel the dialectical backbone of the text in question. Not only did he employ rhetorical categories in the description of painters' styles; ${ }^{2}$ he also elaborated the method that allowed one to reduce commonplaces and rhetorical figures to dialectical Topics and then to reconstruct the syllogistic structure implicitly embodied in speech (declamatio). Melanchthon was inspired in his selection of this line of interpretation by the dialectic of Rodolphus Agricola, De inventione dialectica.

Despite the apparent clarity of expressions Melanchthon employed, the interpretation of the method in question has presented a serious challenge for researchers. In particular, his terminology turned out to be misleading as can be shown by the example of Wilhelm Schmidt-Biggemann. According to him, loci communes lost the traces of their Aristotelian origin in Melanchthon's system. They were no longer formal strategies of argumentation but epistemological, content-oriented key notions establishing individual disciplines. ${ }^{3}$ The reason for this claim was of course that Melanchthon did 
not describe loci dialectici as communes explicitly and thus seems to have limited this term to rhetoric or particular disciplines. That this interpretation is faulty becomes obvious when one compares it with a brilliant analysis by Kees Meerhoff, who succeeds in meeting the subtlety of the relationship between dialectical Topics, Topics ascribed to rhetorical genres (capitula finalia), and ethical commonplaces.

Let us summarize Meerhoff's remarks on technical terms, which will be useful for our further analysis. Firstly, he clearly states that loci dialectici, as indispensable to all disciplines, were considered-explicitly or not-communes. Secondly, he accurately reconstructs two stages of the reduction of capitula finalia to dialectical Topics: capitula finalia (e.g. the Topic of honesty or of usefulness) that belong to the deliberative genre (genus deliberativum) are reducible to ethical commonplaces; and these in their turn, just like figures of thought, are reducible to dialectical places. (For example, one can praise matrimony drawing arguments from the Topic of honesty, which is reduced to the dialectical Topic called on the efficient cause. ${ }^{4}$ ) Finally, Meerhoff arrives at the conclusion that the character of commonplaces of a particular discipline, e.g. theology, was determined by the method of analyzing concepts. In this way, commonplaces conceived of as a kind of encyclopedia-i.e. sources of knowledge for an orator-were closely linked to their dialectical counterparts. While analyzing the first version of Melanchthon's rhetoric De Rhetorica libri tres (1519), Meerhoff highlights the fact that "il insiste à plusieurs reprises sur les liens intimes entre dialectique et lieux communs ainsi que sur la nécessité de cueillir ceux-ci dans les oeuvres des orateurs, des poètes et des théologiens." 5

These loci communes, as Paolo Rossi points out, were an indispensable part of tables among authors of the art of memory in the sixteenth and seventeenth centuries; and according to many Renaissance theorists of rhetoric, among them Melanchthon, they served as a highly important means of restricting and organizing material. As such they bear, as Rossi claims, a resemblance to the impressive enterprise of botanists of the late seventeenth and early eighteenth centuries, which involved the construction of universal tables of natural objects in order to enable memory to keep them. ${ }^{6}$ It should however be pointed out how deeply the continuity of the art of memory was damaged by the decline of the Topical tradition, as announced by Antoine Arnauld in his famous Logique de Port Royal. For Arnauld, Melanchthon's mnemonic loci could be nothing but a useless burden for memory. ${ }^{7}$ This was scepticism, which also shines through in a text by a Russian follower of Linnaeus, whom Rossi quotes: "The authors of ancient times were incap- 
able of a precise terminology not having at their disposal some order for the objects, or some system." 8

For the purposes of my interpretation, it is a hint from the last version of Melanchthon's rhetoric Elementorum rhetorices libri duo (1531) that will be of particular service. It is claimed that correspondence between rhetorical figures and dialectical Topics is based on their essential identity, whereas it is their employment that differentiates them from each other. The domain of dialectic is restricted to confirmation or refutation. Yet particular dialectical Topics are used for the purpose of decoration; they enter the kingdom of rhetoric as oratorical ornaments. Melanchthon considered this correspondence deserving of detailed presentation. It comes as no surprise that comparison (comparatio) also found its place in his system. According to Melanchthon's theory, the congeries of picturesque comparisons from Encomion eloquentiae, intended as the instrument of amplification, belongs among loci ex similibus (Melanchthon enumerated here, among others, locus ex pari, ex maiore, ex minore, exempla and parabolae). ${ }^{9}$ The description of Topics ex similibus in Elementorum rhetorices libri duo is, nevertheless, shortened. This is because Melanchthon programmatically directs pupils to the rudiments of dialectic contained in his manuals, which are intended as something akin to premises, comparable with axioms in geometry. ${ }^{10}$

It is helpful here to refer back to the manual from 1547, Erotemata dialectices. This choice is not haphazard. Suffused with an Aristotelian spirit, it is to a greater degree compatible with the treatises on the soul by both Aristotle and Melanchthon, to which I will make further reference below. In this manual, the correspondence of rhetorical figures and dialectical Topics was presented from a slightly different perspective. It was the point of view of a dialectician as a text critic or an exegete that Melanchthon focused on, and not the point of view of a pupil composing an oration as a beginning rhetorician. This horizon of thought is a useful complement to that sketched above on the basis of Elementorum rhetorices libri duo, because it allows us to grasp the essence of correspondence between truth in a logical sense and truth expressed with the aid of rhetorical figures, and in a broader sense between the assertion of truth and fiction as the imitation of reality.

Erotemata dialectices presents besides the last stage of the development of Melanchthon's views on loci a similibus, under which, as already mentioned, comparisons fell. The definition of these Topics in the two earlier manuals of dialectic was strongly influenced by De inventione dialectica. According to Agricola, similitude was not a real proof. It merely looked like one, because it brought the image of a thing to mind by describing its properties. For that reason, this Topic, along with comparisons, was appropriate for 
affecting the senses of the public and shaping their opinions. As Agricola put this, the slow minds of the multitude (hebetes mentes) are not capable of penetrating the core of things (in ipsas res penetrare) and thus are doomed to the aid of images. The unlearned therefore bear resemblance to the blind who have to grope their way; while people of sharp intelligence (acriora ingenia), like those who can see, have no need for similitude. ${ }^{11}$ Following this pattern in Compendiaria dialectices ratio, Melanchthon excluded locus a similibus from dialectical Topics, these being the sources of necessary arguments. Still, he paid much heed to its usefulness for poets, orators, and historians - as did Agricola. ${ }^{12}$ In the later version of the dialectic manual, De dialectica libri quatuor, we can find also a passage reminiscent of Agricola's remark on the iconic features of similitude: "For they [similia] are the source of weak arguments.... Because of this the following sentence is commonly on the lips of dialecticians: 'every similitude is lame'. However, comparison often has great power because it delights you like a picture of a thing, meeting the eyes." 13

In Erotemata dialectices the skeptical attitude towards locus a similibus, characteristic of the two earlier versions, disappeared under the influence of the late-medieval theory of loci, which Agricola had rejected as being idle formalism. ${ }^{14}$

Agricola's approach to iconicity in argumentation nevertheless betrays an ambiguity that is worth noting. While he came to tackle ways of argumentation that were incomparably more subtle than similitude, he addressed De inventione dialectica to simple people and declared the choice of the appropriate method of lecturing:

I wish to explain these things to the ordinary people, my people, those who are not particularly bright and who are unskilled in these matters, since the learned have no need of a teacher. For this reason I would like not just to say these things, but also to paint or to sculpt them, if the subject would allow it, and I would think I had done well if it seemed not just that I had worked these things out purely for myself, but that my labour would be of use to others and help in their studies. ${ }^{15}$

Agricola's statement that locus a similibus fits simple minds implies that he was aware of the complexity of the subject matter he dealt with in De inventione, and that he expected more from his readers than he declared. Agricola's work in fact turned out to be difficult for humanists, and required an introduction, which purpose Melanchthon's manuals were supposed to serve. ${ }^{16}$ Surprisingly, this paradox was overlooked by the authors of articles on the role of visual arts in Agricola - Michael Baxandall and Peter Mackalthough both stressed Agricola's tendency towards the visualization of lec- 
turing, which had been examined also by Walter Ong in his magisterial book on Ramus. ${ }^{17}$

By referring to the final stage of Melanchthon's views on locus a similibus, I shall try to reconstruct the epistemological foundations of imitation in painting as well as in rhetoric and poetry. The key to understanding this problem is likely to be the notion of absurdity (absurdum), which is identified with falsity. ${ }^{18}$ For Melanchthon, it was codified as locus ab absurdo, and along with other dialectical places as well as loci communes was part of the structure of reality. ${ }^{19}$ Thus the dialectician had to deal with things in the world:

This art (invention) is called topica, i.e. the doctrine of loci which are so to say the indices of things to be either investigated or selected, as when a physician observes a symptom, for example a rapid or unsteady pulse of the artery, he employs the topic called on the effect and knows that he must search for the cause of this sign, this means the source of the pulse, of course, the heart... ${ }^{20}$

Falsity as inconsistency with truth in a logical sense, which Melanchthon had in mind, can be asserted only with regard to propositions (propositiones). Furthermore, this logical procedure requires the employment of criteria concerning an assertion of truth: in philosophy, these are innate notions (principia, id est noticiae nobiscum nascentes, for example numbers in arithmetic), which bear similarity to Stoic koinai ennoiai (koIvai 'Evvolal), ${ }^{21}$ and common experience (experientia universalis); while in the doctrine of the Church (the Protestant Church, of course), moral principles and the articles of faith. ${ }^{22}$ Sentences inconsistent with the criteria above are considered to be apparently false (i.e. false if regarded in a literal sense). At this stage of dialectical analysis, two possibilities emerge: passing a verdict on falsity or applying a rule: decurrendum est ad figuras (it is necessary to resort to figures). This rule facilitates an interpretation that corresponds to the criteria employed. I will clarify this using the assertion of identity of picture and speech suggested by the last sentence of the passage of Encomion eloquentiae. The impression of identity is evoked by the fact that the comparison was subject to condensation and resulted in a metaphor: brevis similitudo. ${ }^{23}$ According to the possibilities described, this assertion of identity either is false or must be interpreted in terms of the application of rhetorical figures, which, as already mentioned, have their counterparts in loci dialectici. ${ }^{24}$

Using the above method of interpretation, one can reconstruct sentences that are immediately true (in that they bear logical analysis), as well as valid syllogisms and consequences. In the Melanchthonian system, the imitation of logical structure in a rhetorical text whose instrument is rhetorical figures, or 
in broader terms, the construction of a fictive reality in poetry, is epistemologically dependent on the rule of locus a similibus, consequently on Topics as such. This premise had broadly influential consequences for the notion of imitation and its iconic function in Melanchthon's theological philosophy. I hope this will become clarified in the course of my argument.

Let us consider more closely the typical characteristics of the locus a similibus in the context of the quoted passage of Encomion eloquentiae. This is a Topic that, unlike Topics such as effect or definition, permits the invention of arguments in farther regions (longius), i.e. the comparison of similar or contrasting things. It is remarkable that in terms of the locus considered, not only may two similar qualities be compared, as in the case of imitative arts (painting, sculpture); so also may functions or duties in society. This is the typically Melanchthonian understanding of Topics as inseparable from moral philosophy, whose certain demonstrations it makes possible. This locus has its specific restrictions: comparing dissimilar parts causes incoherence; it would not be valid, in this case, to draw a consequence from locus a simili. This statement is mirrored in the rule: "A consequence drawn from the Topic a simili (from the similar) is affirmatively valid more often if the parts that accord to each other are compared." "25 It is the dialectical essence of the comparisons from Encomion eloquentiae that Melanchthon gave as an example of a consequence where two species - similar by virtue of being subsumed under the same genus (ars imitatrix) - are taken into account: "In a picture, it is the highest beauty to imitate the natural shapes of bodies as accurately as possible, therefore, in eloquence as well, it is the highest beauty, to display things rightly thought with appropriate speech."26

The next step in tracing the path of Melanchthon's reasoning is to investigate the basis of resemblance between picture and speech and to link it to differentia (difference) eliminated from the consequence a simili. ${ }^{27}$ Both the painter and the orator (or simply the grammarian) imitate reality, that is to say nature ruled by law described by Lutheran natural philosophy. ${ }^{28}$ This imitation is, nevertheless, mediated by images and notions. It is true that in Encomion eloquentiae Melanchthon is somewhat elliptical as to notions; this puzzle, however, can easily be resolved by resorting to a passage from Erotemata dialectices: "As a good painter considers an idea of the deer, and when he sees a monstrous image of the deer disaccord with it, he judges that it is vicious." 29 In the light of this quotation, there is no doubt that animi sententia (the thought of an orator) corresponds to idea (the mental image, which serves the painter as the definition of deer and a pattern to be imitated). ${ }^{30}$ Besides, it seems rather obvious that the two analogical frames of notions underlying the comparison of a rhetorician and a painter-1) things/notions 
(mediated by images or identical with them)/words, and 2) things/images (notions)/pictures - are of Aristotelian provenance. However, there is no question that they underwent considerable modifications. So to grasp the core of the notion of iconicity, typical of Melanchthon, i.e. the correspondence between picture (painting) and word (rhetoric), one has to have recourse back to its sources - in the first place to the treatise De interpretatione by Aristotle. As this section of the Organon was part of the curriculum in Melanchthon's epoch, the scheme of the relationship - things/notions/words - was widely known and acknowledged as binding. ${ }^{31}$ For that reason, it has been taken into consideration by the vast majority of highly valuable studies on Renaissance language conceptions. ${ }^{32}$ However, what has usually been disregarded by scholars of Melanchthon is the relevance of the Aristotelian triad to the notion of iconicity. In all probability, the reason for their disregard is that the meaning of particular terms in Aristotle's concept of language required laborious reconstructions, without which shifts in terminology connecting notions and images were undetectable. Therefore it would seem advisable to reconstruct the Aristotelian frame of notions as carefully as possible and to highlight points whose reception in Melanchthon's philosophy is vague. For the sake of a clear argument, I shall cite the corresponding passage of $D e$ interpretatione in its unabridged form:

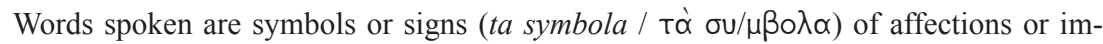
pressions (ta pathêmata / тஷ் $\pi \propto \theta \eta \dot{\mu} \mu \alpha \tau)$ ) of the soul; written words (ta graphomena /

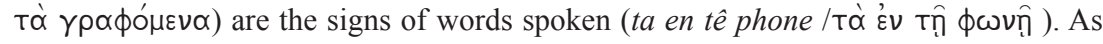
writing, so also is speech not the same for all races of men. But the mental affections themselves (ta pathêmata / т⿳亠口 $\pi \propto \theta \dot{\eta} \mu \alpha \tau \alpha)$, of which these words are primarily signs ( $t a$

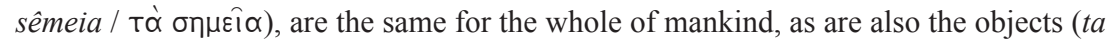

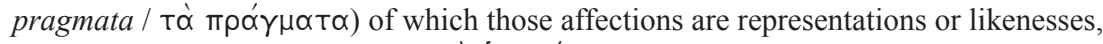

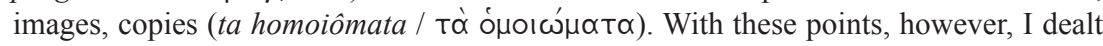
in my treatise concerning the soul; they belong to a different inquiry from that which we now have in hand. ${ }^{33}$
}

Thus, according to the passage above, the scheme under investigation is as follows: ta pragmata - ta pathêmata - ta en tê phôê kai ta graphomena

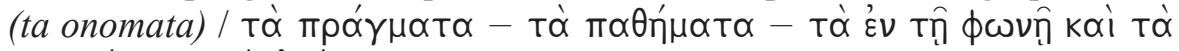

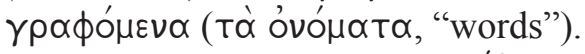

It is the term pathema ( $\pi \alpha \dot{\theta} \eta \mu \alpha)$ that is essential to the notion of iconicity, for there is a relationship of similarity (to homoiôma / tò ó $\mu$ í $\omega \mu \alpha$ ) between this notion and things. The meaning of $\pi \alpha \dot{\theta} \theta \eta \mu \alpha$ oscillates between two poles: image (to phantasma / Tò фóvт $\alpha \sigma \mu \alpha$ ) and notion (to noêma / Tò $v o ́ n \mu \alpha)$. On the one hand, it is possible to put forward a hypothesis about the identity тর́丿 $\theta \mu \alpha$ and image formed on the basis of sense data. However, such 
a hypothesis adopted to the explanation of thought would be inconsistent with Aristotle's statement from De anima, which leaves no doubts in this matter:

But imagination is not the same thing as assertion and denial; for truth and falsehood involve a combination of notions. How then will the simplest notions (ta prôta noêmata /

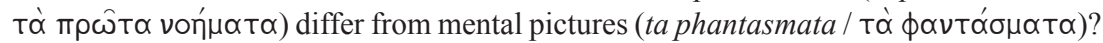
Surely neither these simple notions nor any others are mental pictures, but they cannot occur without such mental pictures. ${ }^{34}$

On the other hand, one can interpret $\pi \alpha \dot{\theta} \theta \eta \mu \alpha$ as a notion in terms of an abstractionist theory of thought. Yet this could exclude the perception of things as such.

Both solutions have of course their supporters among scholars who differ nevertheless in how they overcome the difficulties in question. In his commentary on De interpretatione, John Ackrill opts for the first hypothesis and identifies $\pi \propto \theta \dot{\eta} \mu \alpha \tau \propto$ with images. Still, he states the hopeless vagueness of Aristotle's terminology. Let us quote his remark, frequently referred to in research literature:

What precisely are "affections in the soul"? Later they are called thoughts. Do they include sense-impressions? Are they, or do they involve, images? Aristotle probably calls them likenesses of things because he is thinking of images and it is natural to think of the (visual) image of a cat as a picture or likeness of a cat. But the inadequacy of this as an account or explanation of thought is notorious. ${ }^{35}$

This was a point of departure for Norman Kretzmann in his interpretation of Aristotle's claim that mental impressions are likenesses of actual things. ${ }^{36}$ In his opinion, the main difficulty lies in the fact that this claim fails to make sense of the notion of true and false thoughts, such as a true or false existential thought, e.g. the statement that a tragelaphus exists, which Aristotle gives as an example in the second half of Chapter One of De interpretatione. Kretzmann intends to remove this inconsistency by two steps. First, by referring to the passage from De anima (quoted above), he distinguishes between thoughts and affections of the soul, which Ackrill was inclined to identify. Second, he states that the first half of Chapter One did not concern thoughts, mental entities, or mental acts but sense-impressions or mental images generally. Aristotle regarded thoughts as not belonging to his present subject matter and referred a reader to the treatise De anima. ${ }^{37}$ According to this interpretation, Aristotle confined himself to telling us that spoken signs signify mental images of actual things, and not thoughts. The weakness of this position, as an attempt to present a general theory of 
meaning, is obvious. It is practically impossible to imagine two persons able to indicate identical images using different words. ${ }^{38}$ Kretzmann tries to rescue Aristotle from this reproach and to prove that his scope was only to justify the conventionality of linguistic signification. ${ }^{39}$ As we can see, Kretzmann was perfectly aware of a pitfall hidden in the first solution. To make his argument consistent, he skilfully reconstructs Aristotle's premises in a way that allows him to avoid difficulties. This is possible due to the fact that Aristotle's semantics as a by-product of epistemological or metaphysical investigations requires isolating its implicit premises from a system, of which they are an organic part. ${ }^{40}$ The Stagirite clearly did not mean to work out the theory of semantics for its own sake; he may have thought it unnecessary to present a general theory of signification in the first part of Chapter One. Kretzmann argues simply that the first chapter of De interpretatione is useless in determining an Aristotelian mental correlate of conventional signs. In Kretzmann's argument, there is an implicit suggestion that it could be a form. It is hidden in the statement that the two impressions Smith and Schmidt have of the same triangle are "interpersonally the same in that they have a single Aristotelian form." ${ }^{11}$ Still, Kretzmann leaves the problem unsolved. Semantics plays too considerable role in Aristotelian thought to allow one to take on board so fragmentary a reconstruction.

In the light of this, it is not surprising that Kretzmann faced criticism. The alternative was of course the identification of pathemata and thought that made it possible to include the first chapter of De interpretatione in the reconstruction of Aristotle's general theory of signification. Such a position is represented among others by Ronald Polansky and Mark Kuczewski. ${ }^{42}$ Having rejected Kretzmann's argument, Polansky and Kuczewski tried to show that Aristotle's remarks concern his basic theory of cognition and not images. The core of this theory was the belief - typical of the Greek-that the soul became assimilated or likened to a thing which it cognized. For Aristotle, a key notion is the form, which, as devoid of matter in the sense or mind, makes us cognize the object. Consequently, Polansky and Kuczewski define affections as 'the 'forms without matter' through which in the De Anima we are said to think" (54). Thus cognition is a result of sense or mind being affected by their object. The important point is that the form received is not an image of the object that acts upon mind, but is identical with what is thought of. In this context the difficulty arises how to interpret the term o $\mu o^{\prime} \omega \mu \alpha$ if it does not involve any likeness. The authors suggest that o $\mu$ oi $\omega \mu \propto \alpha$ may emphasize that the thought depends on its object (55). I will return to this point later on. 
The strength of this approach lies in the fact that it identifies the affections of the soul and thought without excluding the sense perception of things, for the same form is supposed to be the subject of cognition of the sense and the mind. As Polansky and Kuczewski put it, while a sense organ incorporates the form of a thing perceived into its matter, the sense itself deals with the form void of matter (54-55).

Polansky and Kuczewski's hypothesis seems to find enough support in Aristotle's works. They offer other passages that speak for the connection between passions and thoughts: the second part of Chapter One, furthermore $23 \mathrm{a} 32-5$ and $24 \mathrm{~b} 1-2$, which prove that affections of the soul are opinions. In this way, they emphasize the discursive character of thoughts (56). This evidence is worth noting. I will try to show that the assumption that forms are necessary to express opinions fails to do justice to the actual role semantics plays in Aristotle's thought.

The solution proposed by Polansky and Kuczewski is of course more consistent with Aristotle's other works than that of Kretzmann. Still, as already mentioned, it betrays imperfections that the authors themselves were aware of. They point out that Aristotle's claim - that thoughts (i.e. forms) were the same in all men because objects that acted upon their senses had the same matters-worked well only in the case of matters about which there was little disagreement., e.g. the matter of water, a chair, and so on. As a result, Polansky and Kuczewski admit that members of the same linguistic community could differ in understanding certain words. For example, such philosophical terms as virtue or the soul are fully comprehensible only to experts, which means that only experts are cognizant of their forms (57).

I shall consider epistemological implications of this problem through a polemic between Travis Butler and David Charles - for the reason that Polansky and Kuczewski's approach comes quite close to the latter. ${ }^{43}$

The core of Charles's argument is as follows: "In cases of successful thinking (as in perceiving) objects in the world liken the thinking faculty to themselves.... When it occurs, the Form is transferred from the object in the world to the thinking faculty." 44 Name signifies a thing through the medium of thought, already produced by the thing "in the Formtransferring way." 45 Possession of such a thought involves locating the significate in the intelligible world order. Charles gives an example of a thought of "man," which requires that "one thinks of man as a certain kind of animal... located on a genus/species tree." If Charles is right, a speaker who is unable to find the position of the significate on the species/genus tree cannot possess thoughts. Instead, he may cognize things through imagination. ${ }^{46}$ As thoughts in Aristotle are indispensable to making judgments, it is clear that such a person 
cannot make any truth-evaluable statements or express beliefs about things either. The example above, given by Kuczewski and Polansky, is useful here. For an Aristotelian, a thought of the soul involves an account that locates it in an intelligible world order, according to which the soul is a life principle that entails "the actuality of a body which itself is potentially alive," 47 and requires acquaintance with Aristotelian metaphysics, as stated by Butler. If it was Aristotle's position, he could not claim that early psychologists (who clearly did not locate the soul in the sense defined above) expressed such beliefs about the soul as for example, "the soul is a type of harmony."48 Butler,

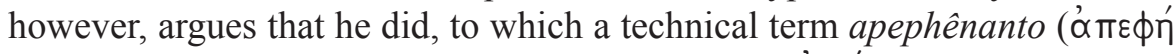

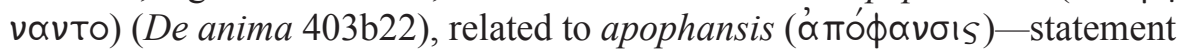
(De interpretatione 17a20ff.), bears witness. ${ }^{49}$ So we can conclude that from Aristotle's point of view a person who is not familiar with Aristotle's metaphysics could express beliefs and make statements, albeit inconsistent with the actual state of things.

In the light of this it is obvious that Kuczewski and Polansky offer a simplistic interpretation while claiming that discursive thoughts have to consist of the forms. Only under ideal circumstances is thought identical with the form. This hypothesis finds support in Rijk's analysis of the semantic shades

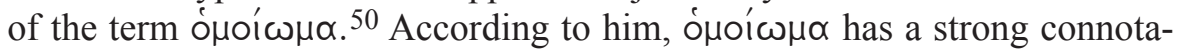
tion of representing, so it goes beyond the focus on the causative origin of thought.

An interpretation that seems satisfying has been proposed by Deborah Modrak. ${ }^{51}$ Her reconstruction of the meaning of $\pi \alpha \dot{\theta} \eta \eta \mu \alpha$ has resulted in the explanation of the semantic ambivalence that appeared to be embodied in this notion. Below I shall trace the main lines of Modrak's argument that are useful for the present study.

Modrak puts forward the hypothesis that Aristotle may not have applied the notion $\pi \alpha \dot{\theta} \theta \eta \mu \alpha$ by chance. If so, we need to consider why he

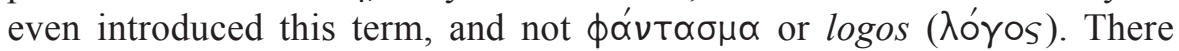
is considerable textual support for both potential substitutes for $\pi \alpha \dot{\theta} \theta \eta \mu \alpha$, so it is easy enough to imagine them in its place. On closer investigation, however, unexpected difficulties arise. This is because má $\theta \eta \mu \alpha$ betrays a certain complexity. In a sense, it proves to be a synthetic notion. This quality comes to light against the background of the reconstruction of the relationship between perception and thought in Aristotle. According to Modrak, there are no convincing demonstrations supporting the assumption that Aristotle differentiated two separate modes of representation: a perceptual representation and a noetic one. Aristotle's intention was to show that only one faculty was involved, though employed in various ways. Two 
functions of $\phi \alpha^{\prime} v \tau \alpha \sigma \mu \alpha$ in particular were the subject of his investigation. First, $\phi \alpha ́ v \tau \alpha \sigma \mu \alpha$ was understood as a representation of a concrete object existing in the world. Second, it could also function as an image representing a universal. In the second case, it was only the common features of particular objects that combined to form an image: they were indispensable for classifying objects into a type. It follows from this that $\phi \alpha^{\prime} v \tau \propto \sigma \mu \alpha$ triggered the formation of a notion: the mind could manipulate it in a way that

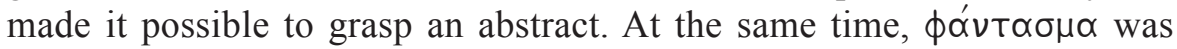
separate from a universal, which is clearly stated in the passage from the De anima quoted above. An image could not form complex unities even in the form employed by geometers: as a token of abstract notion, it could not be used to draw inferences or to conduct logical analysis at all. Only complex thoughts, not images, could be counterparts of propositions. This being the case, it appears to be manifest that had the term $\phi \alpha^{\prime} \nu \tau \alpha \sigma \mu \alpha$ been applied in the passage of De interpretatione under consideration, ambiguity would arise, as it would create the unintentional suggestion that it is the image that is the counterpart of the spoken word. As is known, this solution, though theoretically provable, was unacceptable within the framework of Aristotle's theory of language. In fact, the term má $\theta \eta \mu \alpha$ contained both shades of the meaning of $\phi \alpha v^{\prime} \tau \alpha \sigma \mu \alpha$ : $\phi \alpha^{\prime} v \tau \alpha \sigma \mu \alpha$ as $\phi \alpha^{\prime} v \tau \alpha \sigma \mu \alpha$, the rep-

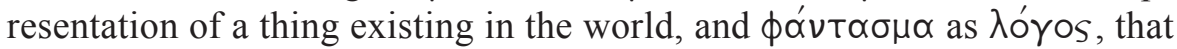
is to say in the form allowing the mind to yield a notion. Consequently, imprecision in the reconstruction of the correspondence things/notions/ words could be avoided. As such, the scheme from the De interpretatione, although requiring the context of Aristotle's other works to be fully understandable, can be regarded as a coherent whole, so there is no need for an artificial complement, which would be necessary if $\pi \alpha \dot{\theta} \theta \eta \mu \alpha$ were replaced

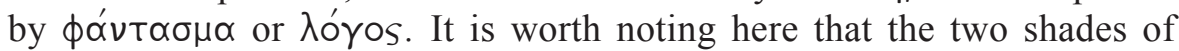
the term $\phi \alpha^{\prime} v \tau \alpha \sigma \mu \alpha$, reconstructed by Modrak had, as we will see, their counterparts among late scholastic authors, who differentiated between similitudo linealis and intentionalis but did not identify perceptual and noetic faculties as Aristotle did.

The next step of our investigation is to find the counterpart of $\pi \propto \theta \eta^{\prime} \mu \alpha \tau \alpha$ in Melanchthon's system. To ensure a clear comparison of both schemes, the Aristotelian and the Melanchthonian, I will begin with a systematic approach, putting aside for a while the influence of Aristotle's commentators, which, in fact, affected Melanchthon's thought.

Two terms can be weighed as counterparts of $\pi \alpha \dot{\theta} \theta \eta \mu \alpha$ in the Aristotelian triad: cogitatio (thought), and imago (image). The most efficient way to define them is to trace actus intelligendi (the act of understanding), especially 
the process of the abstraction of sense data. This method allows one to grasp the moment of the transition of an image into an abstract notion where it took place in a specific epistemological framework.

The treatise Liber de anima (1553) provides a relatively exhaustive description - for an approach more theological than philosophical —of actus intelligendi. I shall reconstruct the particular stages of the mind's activity with reference to the Aristotelian version, which requires us to start with perceptual cognition.

The point of departure is the activity of sensus exteriores (the senses of touch, sight, smell, taste, and sound): perceiving sense data, they construct images of things (simulachra rerum), which Melanchthon described as nuntii mentis (the messengers of thought) and testes experientiae (the witnesses of experience). The term simulachrum corresponds to the Aristotelian $\phi \alpha ́ v \tau \alpha \sigma \mu \alpha$. These images of things excite the action of the mind (intellectus). What follows at this stage can be termed the act of understanding proper. This act involves the image as well. The image is crucial because it allows the mind to execute its proper operations: the cognition of extramental things. ${ }^{52}$ Actus intelligendi is understood as notitia: cognition in the sense of the mind's action (actio mentis). The result of this is notitia as habit (habitus), the mind's durable faculty for cognition. Melanchthon paid more attention to the second meaning of notitia in Erotemata dialectices, ${ }^{53}$ which will serve as a point of reference for the verification of our inferences based on the Liber de anima.

According to Melanchthon, the act of understanding is dependent on sensus interiores: ${ }^{54}$ thoughts (being the images of things) are derived as a result of the brain's motions (spiritus). Let us reconstruct the relationship between imagines and cogitationes with respect to sensory stimuli crucial to them. A number of passages in the Liber de anima and the Erotemata dialectices where the terms imago or species and cogitatio arise lend support to the hypothesis that Melanchthon employed them interchangeably: there is no explanation of how they differ. ${ }^{55}$ In this respect, Melanchthon seems to have resisted the influence of Aristotelian inspiration from the De anima. However, doubts may arise owing to the fact that at the same time he put considerable emphasis on the analytical function of the mind: the dividing and composing of notions. As is known, even this operation of the mind prompted Aristotle to introduce a precise division of image and thought despite having identified a perceptual faculty and a noetic one. This theoretical pitfall, with which Melanchthon as a lecturer on Organon familiarized himself, ${ }^{56}$ needs to be explained in a broader theological context, so I shall return to it later on. 
According to our working hypothesis, then, what results from notitiain the sense of actus intelligendi-is therefore just an image (imago). The imagistic character of the mental counterpart of a spoken word tends to be additionally underlined at the lexical level, through the choice of vocabulary. When thinking of a house, an architect paints a mental picture. Similarly, Lucas Cranach imagines the lines that he is supposed to paint, imitating a mental image. ${ }^{57}$ Painting seems to be the activity of thought. Nevertheless, as in the case of the Aristotelian $\phi \alpha^{\prime} v \tau \alpha \sigma \mu \alpha$, the degree of similarity of the image can differ. It represents either an object perceived or its features common to other objects belonging to the same genus. It is true that this division does not reflect all the subtleties; among other things, the difference between an image being derived while sense and thought are acting simultaneously (notitia intuitiva) (if one is looking at a picture on the wall) and a sensory image or the image of an abstract, stored in the memory (notitia abstractiva). ${ }^{58}$ They are, nevertheless, reducible to the two kinds of image, described above.

How Melanchthon understood the second type of image can be illustrated by a passage from the Erotemata dialectices, reminiscent of De memoria by Aristotle: "Line is length without any breadth and depth, whose extremes are two points. Young men should, however, know that no painted line is the subject matter here but only length abstracted from bodies is to be thought of." 59 This is the definition of a line as a geometrical notion, derived from a line drawn. It is only the constitutive features of the latter that are important for an image regarded as an abstract notion. In view of this, the essence of the relationship between an image of an external object and an image identified with an abstract in the Melanchthonian system can easily be grasped. However, what needs explanation is the provenance of this imagistic universal. I will try to shed some light on this problem.

The difference between the Aristotelian and Melanchthonian understanding of the second kind of image lies in Melanchthon's belief that God created the world according to ideas in his mind (a belief known as "exemplarism"). ${ }^{60}$ While for Aristotle universals were abstracts derived from sense data with the aid of images, from Melanchthon's point of view sense data could offer only a stimulus for the mind, which would not be able to help itself without notitiae nobiscum natae - certain principles that had their ultimate origin in God; what the mind could search for, but not create. ${ }^{61}$ As we can see, the identification of abstract notions and images resulted in a simplistic model in comparison to that of Aristotle. It is true that this caused epistemological difficulties, which I shall characterize below; their overcoming, however, moved the notion of iconicity to the focal point of the Melanchthonian system. 
Having given clear demonstrations, we can now offer a presentation of the Melanchthonian version of Aristotle's triad. It is likely to have the following form: things/images/words, i.e. it was slightly modified. Let us point out its epistemological implications. As already mentioned, it was the incompatibility between an image regarded as a holistic representation and the analytical operations of the mind that was the weak point in Melanchthon's solution. The remarks of the author himself clearly show that he was aware of this; indeed, it would be astonishing if he had not noticed a problem, being a learned Aristotelian and familiar with the Stagirite's commentators. It was, however, theological arguments that spoke for the shift of image in the place of notion. The understanding of notitia as imago gave support for analogy with the Son as the image of the Father, rooted in the Augustinian tradition $^{62}$ and in this way, the Melanchthonian exemplarism could be convincingly justified. ${ }^{63}$ Exempla of the divine Thought—notitiae innatae in the form of images - were a semblance of knowledge about God, which he himself wanted to pass on to humans: "According to a wonderful plan, God wanted notions to be images for he wanted shadows stating something about him to be inside us. The eternal Father contemplating himself gave birth through thought to the Son, who is the image of the eternal Father." 64 Consequently, the human mind had to be a cognitive organ compatible with the whole universe. ${ }^{65}$ The objective that Melanchthon attained with the aid of the notion of image, the epistemological dimension of which overlapped with the theological one, was in fact analogical to that of Aristotle: the correspondence between cognition and the structure of reality was thoroughly cogent in the Stagirite's system due to the equivocalness of the term $\lambda$ óros, which meant a cognitive object, i.e. a meaning as well as the essence of an external object. ${ }^{66}$

The theological dimension being a reference point, it was superfluous to make efforts to overcome the above-mentioned epistemological inconsistency. There was simply no need for an alternative to the Aristotelian distinction between notion and image. So Melanchthon left this problem unsolved consciously, the evidence of which can be found in many passages from Initia doctrinae physicae (1549) and Liber de anima. ${ }^{67}$ From Melanchthon's point of view, such an undertaking would be jejune: the noetic faculty became weaker due to man's fall. ${ }^{68}$ Because of this, the inquisitiveness about epistemology had to be replaced by the silence of prayer. ${ }^{69}$ The process of the formation of images and thoughts remained impenetrable but, at the same time, it shifted towards the dimension of the mystery of the Incarnation. This sheds light on the reasons for doubts raised by scholars of Melanchthon's theological philosophy, who, like Siegfried Wiedenhofer, have not succeeded 
in defining the mental counterpart of the word in the Melanchthonian version of the Aristotelian triad. A comparative analysis of the epistemological foundations of Melanchthon's dialectic and the Aristotelian conception reconstructed in its original form, which I presented above, makes it possible to exceed the utterly negative conclusions of Wiedenhofer, who contented himself with the statement that there is no justification for identifying notions with nominalistic terms within Melanchthon's dialectic. ${ }^{70}$

Besides, the reconstruction of nuances of $\pi \alpha \dot{\theta} \theta \mu \alpha$ in Aristotle and Melanchthon allows us to complement Idea by Erwin Panofsky with respect to epistemology and ancient semantic theories. In this excellent study, Panofsky includes a remarkable passage from Melanchthon's Enarratio libri I. Ethicorum Aristotelis, which he interprets as an attempt to reconcile Plato and Aristotle: "It is certain that Plato everywhere calls Ideas a perfect and lucid notion, as Apelles carries in his mind the most beautiful image of the human body."71

Panofsky rightly states that ideas in Melanchthon ceased to be entities that exist outside both the human mind and the world of sense perception. There is no doubt that Melanchthon took on the position of conceptualism typical of many Renaissance humanists. Still, Panofsky goes too far in claiming that the example of the painter replaced that of the dialectician in Melanchthon's discussions about idea, and that artistic activity was the main domain where ideas manifested themselves. This simplification is due to the fact that while analyzing the notion of idea among particular thinkers, Panofsky does not discern its semantic aspect, which makes the evolution he outlines more sophisticated.

I shall briefly summarize Panofsky's main points. He starts his study with an analysis of Plato's statements about representational art. According to Plato, art was unable to compete with rational cognition. All it could achieve was an image that only reproduced sense-perceptible reality and therefore failed to approach its idea. Thus it was the dialectician and not the painter who could cope with a task of that kind. With time, this gulf was reduced both by art criticism that raised "the object of representation from the level of external, perceivable reality to the level of an internal, spiritual image" (16) and by philosophy that transformed Idea into a mere en noêma/ thought ('̇vvó $\eta \mu \alpha$ ). Aristotle's theory of forms along with Stoic notitiae anticipatae (innate and preceding sense experience) is of particular interest here. According to the Stagirite, "an individual man is "this particular form in this particular flesh and blood'; and as far as works of art are concerned, they are distinguished from the creations of nature only in that their form, before it enters into matter, is in the mind of man"(17). ${ }^{72}$ 
The thinker who reconciled Plato with Aristotle was Cicero. He regarded an artistic idea as a notion immanent in the soul in the Aristotelian fashion. It also displayed absolute perfection in a Platonic sense. However, Cicero's compromise had weaknesses, for he sidestepped the question of how to justify the perfection of notion in the mind.

There were two ways to solve this dilemma. One was to deny that idea was in fact perfect. The other was to prove that it possessed such a quality because it was part of a specific metaphysical system. While Seneca chose the first possibility, Plotinus preferred the second. For Seneca, there was no difference whether the model of the artist was real or ideal. According to Plotinus, who understood idea in a Platonic way, the artists' task, from the beginning doomed to failure, was to subject imperfect matter to higher

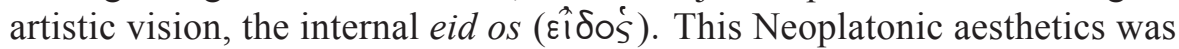
taken over by early Christian philosophers, including St. Augustine. Still, absolute Platonic ideas underwent a metamorphosis into the thoughts of the personal God. The theory of ideas no longer justified perfectly reliable knowledge achievable by man, or his ethical behavior. Its scope was to explain "the meaning and coherence of the entire universe and its unfoldment"(38). Panofsky described this process as a transformation of a theory of ideas from a philosophy of human mind into "a logic of divine thought"(38). Under such circumstances there was no place for an artistic idea in the proper sense. Patterns in the artist's mind, however, emerged in parallel to the divine mind and its ideas. The function of these quasi-ideas was above all explanatory. They helped to clarify and solve theological questions. The other interesting conclusion Panofsky drew was that medieval art imitated nature only in the sense that it worked in a similar way, which means that it did not mimic things in the world directly. As he put it, the work of art arose "by the projection of an inner image into matter"(43). In this respect, Renaissance thinking was totally different from medieval because "it removed the object from the inner world of the artist's imagination and placed it firmly in the "outer world"'(50). According to Panofsky, this resulted from a distance that arose between object and subject: "a distance which at the same time objectifies the 'object' and personalizes the 'subject"'(51). However, this process had nothing in common with the modern "object-subject problem," "73 for it was universally acknowledged that both object and subject were ruled by universal laws, theologically sanctioned (50-53, 63-64). Therefore, idea itself originated in nature and could be discovered or recognized by the artist only as "potentially prefigured in the "objects"'(63). ${ }^{74}$ Panofsky points out that while for classical thinkers, idea was supposed to warrant the mind's independence from na- 
ture, Renaissance thinkers considered ideas as "heightened realities"(65), which gave evidence of a new approach to art.

For reasons of economy, I would like to concentrate on some representative weaknesses in Panofsky's history of idea. As we can see, similar to Kuczewski and Polansky, who identify thought with form, Panofsky characterizes the notion of idea in Aristotle as the form that possessed a definite place on a genus/species tree. This claim rests on the implicit premise that for Aristotle every artist had to be an Aristotelian, which of course was only a desired case. ${ }^{75}$ The following passage concerning the status of sentences in poetry and rhetoric clearly disproves this:

But while every sentence has meaning, though not as an instrument of nature but, as we observed, by convention, not all can be called propositions. We call propositions those only that have truth or falsity in them. A prayer is, for instance, a sentence but neither has truth nor has falsity. Let us pass over all such, as their study more properly belongs to the province of rhetoric or poetry. ${ }^{76}$

In the same way, Panofsky sidesteps the relationship between notion and idea among Neo-Platonists, who adapted the Aristotelian triad to their semantics. ${ }^{77}$ I shall expand on it by adducing the example of Ammonios later on.

Also, the analysis of St. Thomas's conception of idea is incomplete. Panofsky seems to have understated St. Thomas's argumentation in Quaestiones disputatae de veritate, although he refers to it. This treatise disproves Panofsky's claim that the artist's mental pattern was a kind of quasi-idea, which also seems inconsistent with Aristotle's theory of forms taken over by St. Thomas. As a specific sort of form in the human mind, idea had a lower position in epistemological hierarchy than God's patterns. Nevertheless, it was significant:

Third, the form of a thing can mean that according to which a thing is informed. This is the exemplary form in imitation of which a thing is made. It is in this meaning that idea is ordinarily used. Hence, the idea of a thing is the form which a thing imitates. ${ }^{78}$

In addition, the mechanism of imitation sounds more sophisticated. As St. Thomas explicitly stated, the artist could also imitate external objects as perceived through the senses transferring images to the intellect.

For we say that the form of art in the artist is the plan or idea of the artistic product, and we also say that a form outside the artist is a plan if he imitates it when he makes a thing. This, therefore, seems to constitute the character of an idea: It must be a form which 
something imitates because of the intention of an agent who antecedently determines the end himself. ${ }^{79}$

Panofsky is right to say that imitation was not direct, but he failed to discover reasons for this. For St. Thomas, man's mind cognizes things by forming species intelligibiles that represent the pure forms of the things. This acquisition of representation in the mind was often called similitudo because the mind became assimilated to the thing cognized and could possess knowledge about that thing even if it was not present or no longer existed. ${ }^{80}$ Species, however, like forms in Aristotle, are not identical with concepts: "Words do not therefore signify the intelligible species themselves, but that which the intellect forms for itself for the purpose of judging of external things." 81

In such an approach, a direct access to material things was of course impossible. Thus the act of imitating external objects as in the case of the painter had to be referred secondarily to universals. Still, it was not a common position. Panofsky does not take into consideration thinkers who, like William of Ockham, combated species-theory and whose views on aesthetics consequently had to differ from these of St. Thomas:

For [idea] is nothing else than a thing cognized upon which as a pattern one who cognizes looks in order to create something similar or this thing itself in real being. Like one house can be accurately called an idea and an exemplar of another house, because by cognizing that house an artisan can naturally build a similar one. And in the same way, if a specific house being an individual thing was precognized by an artisan and thanks to this he could create the same house, this house, which an artisan could create in real being by looking upon it, would be an exemplar and idea of itself. ${ }^{82}$

Panofsky is also right to say that in such a system as that of St. Thomas there was no place for an artistic idea for its own sake. It is however worth pointing out that St. Thomas consciously put aside cases of artistic imitation irrelevant to his theory of cognition. To him, the artist could imitate an object also by chance. In this case, similar to the example of a skilled artisan or a doctor, given by Charles, ${ }^{83}$ no idea was involved. ${ }^{84}$ Therefore we can conclude that St. Thomas's criticism of art was at the service of his epistemology, underestimated in Panofsky's study.

Also, as already mentioned, Panofsky's interpretation of idea in Melanchthon is simplistic. He defines it as a pattern in the mind but does not set it against either its epistemological genesis or the dialectics of Melanchthon, whose aim was to enable one to discuss potentially every subject. ${ }^{85}$ In fact, the painter and the dialectician could not be opposed for Melanchthon, because in order to cultivate his art, the painter (like the 
physician) had to have dialectical skills. So in light of the fact that idea as a definition of a thing ${ }^{86}$ was indispensable to all disciplines, it is not surprising that one can come across Apelles's metaphor in passages on medical subjects, too. ${ }^{87}$ There is of course a resemblance between Ockham's definition of idea, quoted above, and that of Melanchthon. While for the former, idea was an object cognized which served as an exemplar for producing a similar object or simply itself (for God, idea was nothing else but creature), the latter considered it to be knowledge at the mind's disposal (in the case of God, these were divinae ideae, which showed a slightly Platonizing flavour overlooked by Panofsky). However, this similarity proves superficial on closer examination. The passage from Enarratio libri X. Institutionum Oratoriarum Quintiliani, where Melanchthon explains how to use patterns in translations from classical languages, is particularly instructive: "When I am translating a speech by Demosthenes, I must conceive a certain idea of this republic in my mind and I appear to see a shape of the Athenian republic before my eyes and to stay there. This thought itself is very helpful throughout a life." 88 For Melanchthon, idea as a definition enabled one to acquire historically changeable notions, while for Ockham it was a mental term (nomen connotativum, vel relativum secundum alium modum loquendi), as part of ahistoric universal language. ${ }^{89} \mathrm{I}$ will return to this point later on.

As we can see, the method employed allows us to outline shifts in the Aristotelian triad, under the layers of transformations often caused unconsciously by Aristotle's commentators and followers, whose aim was to cultivate philosophy and not to reconstruct the Stagirite's system. ${ }^{90}$ It was also useful to show some gaps in research literature, which resulted from an overlapping of notions. The causes and significance of these shifts for Melanchthon's theoretical awareness are, however, not wholly understandable without the backdrop of the tradition, so it is necessary to present it briefly.

From my point of view, two sources are of particular import: the commentary on De interpretatione by Neo-Platonist Ammonios, and two commentaries on the same treatise by Boethius, whose interpretation, as has been proved, was influenced by the former author. ${ }^{91}$ These two authors commented directly on the terminology contained in the first chapter of De interpretatione. Melanchthon's inspirations were of course much more variegated. In particular, Galen, whose medical and logical works enjoyed immense popularity during the Renaissance, ${ }^{92}$ should be acknowledged here. For Melanchthon, medicine was part of a general education indispensable to everyday life, ${ }^{93}$ but which in its turn required dialectical rudiments as testified by the passage on symptoms from Melanchthon's Erotemata dialectices. Despite his 
Aristotelian distrust of rhetoric and poetry as a means of scientific research, Galen provided a distinguished pattern to follow in dialectic. ${ }^{94}$ His views on language, scattered through his medical treatises (from which Melanchthon made excerpts), corresponded to the Aristotelianism of the latter. As R. J. Hankinson cogently showed, Galen opted for conventionalism and fervently combated Stoic etymological inventiveness, e.g. Chrysippus's claim that the rational soul must be located in the heart, as while pronouncing ' $\gamma$ $\gamma$ ' we nod towards our chest and consequently towards the heart. ${ }^{95}$ To take an example: in the treatise On the Doctrines of Hippocrates and Plato we can find interesting remarks on the motivation of names, crucial to Melanchthon's views on semantics:

We use names and linguistic communication generally in order to express the thoughts in our mind that we have gained from examining the nature of things. It is ridiculous, then, to abandon this pursuit and quarrel about names. ${ }^{96}$

The focus on the study of natures resulted from Galen's strong aversion to terminological disputes, which he considered irrelevant to physicians, ${ }^{97}$ but it was also consistent with many humanists' views. ${ }^{98}$

Melanchthon's knowledge of Galen's works related to language was nevertheless limited. He could not know Galen's treatise De nominibus medicis, for only its first part survived in Arabic version. ${ }^{99}$ In addition, Galen's commentary on De interpretatione, which would enable one to reconstruct his views on the notion of pa/qhma, as well as the treatise on the correctness of names and on the word and its signification, were lost. ${ }^{100}$

In all likelihood, it was the commentaries by Boethius that were of decisive importance for the reception of the Aristotelian triad. Pursuing Ammonios, ${ }^{101}$ Boethius unmistakably interpreted $\pi \alpha \dot{\theta} \eta \mu \alpha$ as a notion (conceptus). ${ }^{102}$ Both commentators were, of course, perfectly aware of the role $\phi \alpha ́ v \tau \alpha \sigma \mu \alpha$ played in Aristotle's approach. However, as we can see, they did not attach importance to the nuances reconstructed by Modrak, which consequently led to a simplification of its primary significance. The Aristotelian triad finally took on the following shape: res / conceptus / verba. At the same time conceptus (notion) assumed the characteristics of the second type of image. So, the notion itself became a bearer of similarity (similitudo). Therefore, neither Ammonios nor Boethius posed a question of how it was possible for a notion to be similar to an extramental object. Thus, they sidestepped the problem that, in all probability, inclined Aristotle to the employ-

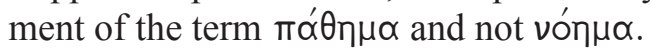

Still, a certain ambiguity of Ammonios's notion of iconicity seems significant. In the comments on the lines $2-5$ of De interpretatione (These spoken 
forms... ) he characterized notions being the pictures of things as the same in all people. ${ }^{103}$ Yet, in the passage on the lines 11-13, where Ammonios combats arguments against physei-theory, we find a subtle analysis of semantic differences between concepts related to the same substance:

But concerning the multiplicity of appellations we say that it does not at all prevent each of them from being appropriate to the thing named; because just as it is possible that there are several pictures of the same man, maybe in different material, copper or wood or stone, but all of them bearing his likeness (pasas de echousas tên pros auton homoiotêta

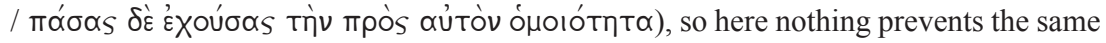
substance from being named by means of different syllables, one and the same thing being signified now after this, now after that conception of all /possible ones/, (oú $\delta \dot{\varepsilon} v$

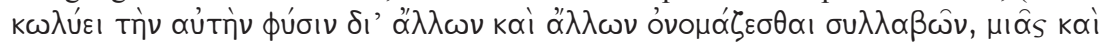

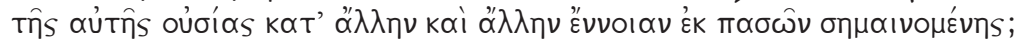

ouden kôlyei tên autên physin di' allôn kai allôn onomazesthai syllabôn, mias kai tês autês ousias kat' allên kai allên ennoian ek pasôn sêmainomenês) ${ }^{104}$

Ammonios gave as an example appellations of man, which, like different pictures of the same person, refer to his individual features, e.g. he can be called brotos (ßрото́s) "because of the fall of the soul into birth and the taint resulting from it" or merops $\left(\mu \varepsilon^{\prime} \rho \circ \psi\right)$ "because of the use of articulated voice."105

This paradox is a key to Ammonios's understanding of the deep structures of Greek. As Hans Arens rightly states, in the first passage Ammonios focused on the species conceived as the sameness, which was a result of abstraction from uncharacteristic features. ${ }^{106}$ What is stressed in the second passage are differences in representing the same substance. This clearly proves that Ammonios did not regard semantic deep structures as universal and common to all languages, but as proper to Greek. In this respect, he expanded on Aristotle's semantics. Thus, his position concurs with Melanchthon's views as presented in the passage on the idea of the Athenian republic. At the same time, it is different from the approach of medieval logicians, e.g. Robert Holkot or William of Ockham. I will return to this later on in order to present a synthetic view.

Although in Boethius the role of notions in logic did not differ from that in Aristotle, Boethius unintentionally laid the foundation for blurring the distinction between image and notion, which continued in Melanchthon's approach. In the light of the above, it seems of particular importance to investigate whether the term imago in Melanchthon corresponds-with regard to the context, of course - to intellectus, having the features of the image of an abstract notion, in Boethius. If the answer is positive, the assertion of the common mental counterpart of speech and image, which implies the crucial 
role of iconicity in Melanchthon's system, would turn out to be an overinterpretation. Hence the significance of the problem.

This kind of ambivalence in the employment of the term imago (and other terms with the same meaning) can actually be traced to some medieval logicians. Fitted with the standard dialectical education, Melanchthon must have been well familiarized with their way of argumentation. I shall confine myself to four examples of the striking employment of the term imago or species instead of conceptus. The theoretical foundations of their interchangeability have been clearly codified in the treatise De sensibus by Walter Burley. He stated univocally that: "Intellect is called imagination with regard to the similarity of their operations, because they always work together in their operations and because nothing is grasped without a phantasm or imagination." ${ }^{107}$ Consequently, complexa, among other things, a proposition-a sentence in a logical sense - operating on notions, corresponds to incomplexa: species, similitudo, intentio. Along with a wide range of synonyms of the term notion, Robert Holkot also enumerated a species and an image:

And this is what he says in the first book of De interpretatione where he claims that the likenesses of things, which are sometimes called concepts or ideas or images or pictures, sometimes notions, sometimes intentions, sometimes mental verbs, sometimes thoughts, sometimes understandings, sometimes the passions of the soul, "these are, I say, the same in all the people" this means equivalent in signifying or representing "because also things are the same in all people," for such likenesses are caused by things and they do not signify things whose they are likenesses by convention but naturally.

And later: "Sometimes concept is, in fact, a picture when it represents an extramental thing; sometimes it is not." 108

A systematization of the different meanings of species can be found in Tractatus de anima by Peter d'Ailly, whose commentaries on the Peter Lombard's Sentences Melanchthon referred to as one of the works Luther knew by heart: 109

First of all it should be however known that although the name 'species' is equivocal in various ways, it usually is understood in four ways as far as the topic of notions, which we are discussing, is concerned.... In the third way "instead of every form which is likeness and image of a thing known and by which this thing is cognized", and thus actual cognition is sometimes called a species too. ${ }^{110}$

A detailed analysis of the conceptions created by the logicians in question is unnecessary here since the passages quoted provide sufficient evidence for the statement that the metaphorical use of term imago-i.e. in the context where, according to the premises acknowledged, conceptus would be 
expected-was conscious and purposeful. This semantic shift was intended to highlight the correspondence between conceptus and res: the ability of conceptus to be similar to a thing, and thus a property that Boethius ascribed to notion. Logical operations can therefore be conducted on notions with the features of the second kind of image.

In Melanchthon, this background of the employment of imago vanished almost without a trace. What seems to be the only remainder of it is the operations of intellect—compositio and divisio 111 — which, as mentioned above, could not be conducted on images. Melanchthon's dependence on scholastic shifts in terminology is, however, rather obvious. In consequence, one can risk a hypothesis that the role of image or, in broader terms, iconicity in Melanchthon's theological epistemology is derivative. He did not intend to create any imagistic theory of thought; the context where image could function metaphorically without causing misinterpretation lost its importance for him. As a result, the sharp distinction between semantic and theological planes proved insignificant, which Melanchthon did not hesitate to exploit to gain the coherence of his system.

In order to arrive at a proper understanding of the role of iconicity in Melanchthon, it seems necessary to find the main reason why the Aristotelian model of the operations of intellect suffered simplification. To all appearances, this was a result of the increasing importance of language (Latin, above all) understood in a historical and eclectic way, which took on the function of the intellect's epistemological instrument. As a device compatible with reality, language was not only a bearer of logicalness, but it also served cognition marked by the human mind's inventiveness. Accordingly, Melanchthon transcended even those medieval logicians who considered logic as ars sermocinalis and assumed a solution that would be unacceptable to the Stagirite due to his mistrust of language. ${ }^{112}$

These results coincide with the conclusions Kristian Jensen and MarieLuce Demonet reached with respect to another Renaissance Aristotelian, Julius Caesar Scaliger, who explained process of cognition by the metaphor of a mirror:

As in the mirror things that appear are not visible but their images, which is certainty the reason why they are called "images"...: so also are things that we perceive in fact outside us and their images in us. Indeed our mind, to which things manifest themselves only through senses, is so to speak a mirror of things, it knows nothing by itself. ${ }^{113}$

As Jensen rightly states, Scaliger used the term "species" to describe both a reflection and a universal. Although he was aware of the equivocalness of this term, he apparently did not attach importance to the distinction 
between mental image and concept. The metaphor quoted above clearly blurs it by suggesting the iconic relationship not only between thing and mental image but also between thing and concept. According to Jensen, Scaliger believed that the mirror of intellect was a nearly transparent medium, which made the mental level almost redundant. To him words signified mental terms, which in their turn were likenesses of things in the world. Yet the role of signification was so trifling that the relationship between mental terms and things was almost objective. In this respect, Scaliger came close to Agostino Nifo, who denied that natural significance existed and claimed that humans received notions objectively. ${ }^{114}$

Demonet also points out the close relationship between concepts (the forms of things) and mental images in Scaliger's linguistic theory. ${ }^{115}$ Her claim, however, that Scaliger restituted the visual relationship between concept and a designate, which coincided with a similar trend in new translations of De interpretatione, does not find enough support in texts. I shall quote a crucial passage, which shows Melanchthon's and Scaliger's terminology in its contemporary context:

En revanche, les traductions d'omoiomata indiquent une évolution assez nette vers la visualisation du concept: si l'on trouve encore similitudines chez Rasarius (1545) et Charpentier, elles deviennt simulacra chez Sylvanius, Rasarius (1559), Hannonius et Pacius, et species chez Périon et Grouchy; cette dernière façon de restituer la relation visuelle entre le concept et le référent est tout à fait en accord avec la description que Jules-César Scaliger fait à la même époque $(1540,1561)$ des notiones de l'âme, comprises comme des species, formes ou images des choses.... En même temps, l'écart théorique se réduit entre les images des choses dans l'entendement et les res abstraites; pour preuve, les nouvelles traductions des pathemata en tè psuchè qui, même si l'on trouve encore passiones, peuvent être diversifiées en affectus (Sylvanius, Charpentier, Grynaeus), sensa, comme on l'a vu chez Périon mais aussi chez Rasarius (1545 et 1559), et notiones chez Hannonius. ${ }^{116}$

The objections that one can raise against Demonet's interpretation are as follows: The thesis of the restitution of the visual relationship between a designate and concept suggests its discontinuity. The passages from medieval logicians quoted above, in particular Holkot's comments on De Interpretatione, disprove this. Of course, a different approach was also possible, but it was by no means prevailing. For example, some Albertists, among them Heymerich van den Velde (Heimericus de Campo), believed that the embodied human intellect can think without images. In his treatise Problemata inter Albertum Magnum et Sanctum Thomam (1428), Heymerich erroneously ascribed this view to Albert the Great and rejected the opposite position as Thomistic. His interpretation influenced Nicholas of Cusa, who also took on an Albertist 
position on the role of images in cognition. In the brilliant study of Albert's influence on late medieval psychology, Katharine Park shows that the theory of thinking without phantasmata was reminiscent of the Pseudo-Dionysian psychology that formed part of tradition. ${ }^{117}$

It is true that the iconic relationship in Scaliger or in Melanchthon can be understood as blurring the distinction between similitudo linealis (likeness iconic in the proper sense) and similitudo intentionalis (i.e. involving a natural representation), which was common among the fifteenth- and sixteenth-century logicians. ${ }^{118}$ Yet the same does not hold in new translations of De interpretatione. Demonet herself observes that Sylvanius did not remove ambiguity of the term má $\theta \eta \mu \alpha$ (pathêma), which the original suggests as he translated $\pi \propto \theta \eta \dot{\eta} \mu \alpha \tau \alpha$ as affectus that are simulacra rerum, but later on

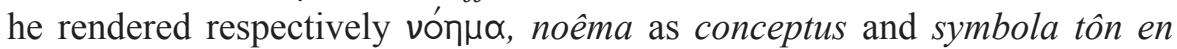

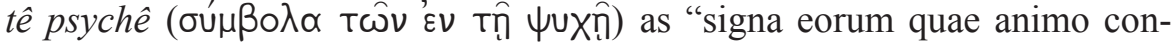
cipiuntur," which can mean both image and concept. ${ }^{119}$ Similarly, there is not enough support in the commentary by Joachim Périon, who rendered pathêmata as mens and then as sensa animi, sensus animi and "intelligentiarum et notionum quae in animis imprimuntur interpres est oratio." 120 As noticed by Demonet, by the employment of the term mens Périon aimed at integrating the Aristotelian definition with the notion of mental word among theologians. In his commentary, he clearly distinguished between two stages of cognition:

For all things perceived through the senses are the same, and these that affect senses, affect the mind in the same way: these that are imprinted in minds, incomplete concepts discussed above are imprinted in all people in a similar way.... ${ }^{121}$

It is clear from the foregoing argument that Demonet's interpretation should be complemented. As well, the replacement of Boethian similitudo by simulacrum or species does not seem haphazard. On the contrary, the fact that Giovanni Battista Rasario thought it necessary to follow the version of Joachim Périon and Nicolas de Grouchy and to correct his own translation proves that it was an important detail. Furthermore, it is remarkable that this tendency prevails among translators equipped with a humanist education, whose aim was to bring their versions closer to Aristotle's original terminology. For example, for Thomas Bricot, a nominalist, who based his logic teaching on John Buridan's Summulae (and therefore did not go beyond the scholastic approach to language), ${ }^{122}$ this shade of meaning was not recognizable. ${ }^{123}$ It might have been discernible for Jacques Charpentier, a famous opponent of Peter Ramus and an outspoken Aristotelian. ${ }^{124}$ However, unlike Périon, who after all employed a Ciceronian expression, ${ }^{125}$ Charpentier left 
the Boethian version of the term ó $\mu$ oi $\omega \mu \alpha,{ }^{126}$ which I will try to explain below.

Let us compare the semantic fields of similitudo and species or simulacrum, taking as a point of reference classical Latin, which was the pattern used by humanists.

It is notable that however different their semantic fields, the words species and simulacrum have one meaning in common. They connote the ability for representation: the ability to be substituted for something else. The fragments from Cicero clearly testify to this. In the second book of De oratore, Antonius alludes to this signification of simulacrum while discussing the art of memory invented by Simonides. ${ }^{127}$ As for species, we can find a similar shade of meaning in De divinatione. ${ }^{128}$

Thus, the above variants come closer than similitudo to the meaning of o $\mu \sigma^{i} \omega \mu \alpha$. What is more, they can imitate the nuances of ómoí $\omega \mu \alpha$ as an Aristotelian term. For the Stagirite, ó oi $\omega \mu \alpha$ had just such a shade, which has been, as already mentioned, cogently proved by Rijk. ${ }^{129}$ To all appearances, the translators, who employed species or simulacrum, showed more understanding for the finesse of Aristotle's terminology than did Boethiuswhich might be surprising, at least in the case of humanists often accused of a lack of philosophical refinement. In Aristotle, the ability of $\pi \alpha \dot{\theta} \theta \eta \mu \alpha$ for representation was of the highest importance, as it justified the implicit postulate that the semantic deep structures he explored were not common to all languages, but proper to Greek. Similarly, among idealistically oriented humanists, the conception of language as a historical product involved a dynamic character of deep structures, which could develop. I tried to show this by analyzing Melanchthon's notion of idea, in particular the idea of the Athenian republic. The ability for representation, connoted by the term óoí $\omega \mu \alpha$, was also a valuable basis for this approach. In the light of this, it becomes clear why (among others) Charpentier, whose approach to deep structures had a Boethian (and hence scholastic) flavour, did not render this shade of meaning. He was simply not interested in this aspect of the relationship between the surface level of language and its deep structures. ${ }^{130}$

This does not mean, of course, that the connotation in question automatically determined the nature of deep structures. The notion of mental representation played a significant role as well in the Middle Ages, at least from the fourteenth century. ${ }^{131}$ It referred, however, to universal mental language as I showed by adducing the example of Ockham and Holkot, and did not involve the reinterpretation of deep structures in terms of the original Aristotelian semantics. ${ }^{132}$ Its employment was therefore rather restricted. 
To illustrate the ontological dimension of language, let us refer to the above quoted passage from Encomion eloquentiae. A deeper layer of Melanchthon's reflection can be noticed only at this stage of analysis. It is monstrosus that seems to be a key word suitable for discovering it. ${ }^{133}$ The deformation of linguistic form involves the distortion of its content. This is the reason why incongruity between speech and the structure of reality arises. The sources of distortion are in fact monstrous images, to which words refer the mind. To clarify how it works, it is useful to look back on Melanchthon's characterization of Dürer's style in a letter to a prince Georg von Anhalt (17 December 1546), which aroused vivid interest among researchers:

I remember that the painter Albrecht Dürer, a man of prominent talent and ability, once said, in his youth he loved paintings with lively and variegated colors and as an admirer of his own works, he had often taken great delight in contemplating this variegation in some picture of his. Later, as an older man, he had begun to look at nature and attempted to consider its original appearance; at that time he understood that just its simplicity was the highest ornament of art. When he was not altogether able to reach it, he had, as he said, no longer admired his works as formerly, but often sighed when he contemplated his paintings, and thought of his weaknesses. When I consider how thorough was the occupation of this man with an art which is not the most important, it often causes me grief and arouses my indignation that our position in the simplest scientific explication of the divine teaching is not undertaken with the same care. ${ }^{134}$

According to Białostocki, this story must have been of considerable import for Melanchthon, as he repeated it about ten years later in a letter to the theologian Albrecht Hardenberg, ${ }^{135}$ where, remarkably, he employed the same expression as in the passage of Encomion eloquentiae quoted above: "monstrous and unusual figures" (monstrosae et inusitatae figurae). ${ }^{136}$ This is because, as Donald Kuspit argued, Melanchthon held Dürer, who offered "the deepest revelation of the human and the divine, a revelation so direct and simple that it seemed inevitable and indisputable," in particularly high esteem. His mature style surpassed Lucas Cranach the Elder and Matthias Grünewald, both being rather provincial masters, whose simplicity resulted from ignorance. ${ }^{137}$ Białostocki sees in Dürer's dilemma the conflict of two opposite tendencies: striving for clarity and indulging a violent imagination, capable of producing dreams about wonderful pieces of art as well as terrifying visions. ${ }^{138}$

For Melanchthon, imagination was a source of a similar subliminal tension set against a clearly religious background. In one of his poems, written in 1541, on occasion of the conference in Ratisbon, which Emperor Charles $\mathrm{V}$ convened in the vain hope of unifying the western Church, Melanchthon described a scary dream: 
Me iussere Duces fallacem pingere Hyaenam, Et monstri speciem proposuere mihi. Tetra erat ex variis moles confusa figuris, Tectaque liventi sanguinolenta cute. Virginei vultus, sed torva micantia flammis Lumina saevitiae tristia signa dabant. A collo gemini pendebant membra Draconis, Scillaei tandem pars erat ima pedes. Horrebam aspiciens, et toto corpore sanguis, Ac pene exstincto sanguine vita fugit. Ut pingam tamen illi urgent, non obsequor, aio Iratus, pingi non bene posse pedes. Quo ruitis proceres? Qui mentes occupat error? Cur templo infertis talia monstra Dei? ${ }^{139}$

The hyena, which the princes forced Melanchthon to paint, was the Ratisbon Book, a compromise statement on justification prepared by Catholic theologian Johannes Gropper, and discussed during the conference in Ratisbon. Melanchthon and Luther earlier read its manuscript, which they had received from Joachim II, Elector of Brandenburg, but neither displayed enthusiasm. Melanchthon even wrote on it: Politia Platonis, i.e. utopia. ${ }^{140}$ Indeed, he was right. The Ratisbon Book turned out to be a utopia, which had been anticipated by the scary dream. The picture of the hyena as an antithesis of the stoic and humanist ideal of natural symmetry ${ }^{141}$ expresses the impossibility of reconciling Catholic theology with the Protestant search for simplicity. Melanchthon sharply criticized sophistical theologians, whose subtle argumentations bore similarity to the pictures of chimeras and centaurs, as being extremely colourful and complex:

You see, with which colors ingenious men are now painting misuse in the Church, with which arts they destroy true sentences, how many wise medicaments they find out in order to remedy absurd opinions as often as things go so far that one must either think up artifices or rush on certain death. ${ }^{142}$

This supports Donald Kuspit's claim that Melanchthon's admiration for simple style was deeply rooted in his dilemmas as a theologian. According to Melanchthon, scholastics' subtle speculations obscured the Gospel. ${ }^{143}$ His aim was to restore its clarity by focusing on the Topics of Law and Gospel and applying to theology the lucidity of his dialectical method. The tendency for theological simplicity shone through also in the reduction of the multitude of Catholic sacraments to an essential few, and in the simplification of the 
notion of holy, ${ }^{144}$ which manifested itself in ecclesiology and in the doctrine of justification. Melanchthon believed that after God and His Word the Church deserved the highest respect, but he refused to limit the agency of the Holy Spirit to the Church hierarchy. ${ }^{145}$ As for the doctrine of justification, he preferred it also because of the simple style: “.... the mode of speaking 'faith justifies' is helpful because it is easy to understand. The meaning of faith is not obscure...."146

These concepts were taken over by painters who, like Lucas Cranach the Elder, made use of Protestant dialectic in their works. Cranach's famous painting The Law and The Gospel, whose numerous versions and copies testify to its popularity as the gist of Lutheran doctrine, is of particular interest here. ${ }^{147}$ I shall recall some main motives of the version from 1529 , as presented by Frank Büttner in the essay on argumentatio in painting during the Reformation. ${ }^{148}$ On the left hand side of the picture, we see a naked man driven to hell by Death and the Devil. Watching this scene, Moses, accompanied by other prophets, points at the Decalogue. In the background, Christ as Lord of the World judges man in heaven. To the right, there is a naked man with hands raised in a gesture of prayer. John the Baptist shows him the crucified Christ, depicted before the open grave. In this part of the picture, Death and the Devil are defeated, and above the grave Christ is ascending to Heaven.

According to Büttner, there is no absolute antithesis between the two parts of the painting, the Law and the Gospel. ${ }^{149}$ Such an interpretation, though accepted by many scholars, ${ }^{150}$ is theologically incorrect. The painting seems to reflect Melanchthon's doctrine of loci theologici, in particular the Topic of Law and the Topic of Gospel, and displays a hidden syllogistic structure to be reconstructed by viewers in the Agricolian fashion. ${ }^{151}$

To sum up, while close connections between painting and dialectic at the service of theology are beyond doubt, Kuspit's thesis on the superiority of the former to words does not find enough evidence in Melanchthon's dialectic. Like Panofsky, he overstates the role of painting in Melanchthon. I shall quote a remarkable passage from Declamatio in laudem artis medicae, where a slight distrust of representational art shines through declamatory convention: "For in this discipline, as opposed to painting, it is not vain shadows and deceptive pictures of bodies that delight us but substantial things and the living work of nature, whose incredible and variegated beauty is watched with greatest pleasure."152

In the light of the above, it can be concluded that for Melanchthon the external shape of language, its natural simple form, ensures harmony with reality as its indispensable part. The assertion of truth as the correspondence 
with the real state of things cannot, therefore, be based on notions mediated by words only as far as the necessity of communication is concerned (which was Aristotle's intention), for it depends on the historical shape of language restricted by common use that places limits on the liberty of creating ahistoric specialized jargon like that of Aristotle or scholastics. In Melanchthon's system, the external form of language is, accordingly, a picture of reality; ${ }^{153}$ analogies between language and painting scattered through his works reach the essence of these two kinds of human activity. With a view to their identical mental counterpart imago enriched by a theological dimension, the Protestant doctrine of imago - similitudo, we can risk the statement about the iconic nature of this essence. However, for the purpose of proving this hypothesis convincingly, it is necessary to take into account the main difference (differentia) between painting and speech, which I mentioned in general terms while analyzing the structure of the consequence a simili, presented in Erotemata dialectices. The difference under consideration lies in the discrepancy in ways of signifying the mental counterpart (and, consequently, an extramental object), as only a picture can mirror reality in a properly iconic manner. A linguistic sign is, by rule, conventional. In this respect, Melanchthon remained faithful to the Aristotelian theory from De interpretatione, according to which spoken words are the tokens - conventional signs - of paqh/mata, and written words are the tokens of spoken words. To take an example, clear testimony of Melanchthon's approach can be found, among other things, in Encomion eloquentiae. The following remark leaves no place for doubt: "Because words become acceptable through usage like coins, it is necessary to employ the words received that are devoid of obscurity, for eloquent men passed them on to posterity so to speak by hands." 154

However, in the other treatise, the already quoted Liber de anima, Melanchthon resorted to a startling juxtaposition, apparently not of Aristotelian provenance: verba - notae picturaeque rerum et cogitationum. ${ }^{155}$ Nota is a standard Boethian translation of the terms employed in De Interpretatione:

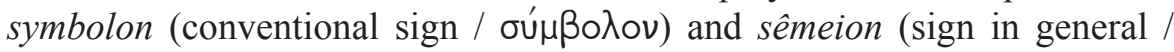
опнघiov). What remains unsolved is the puzzle of pictura, referring to the area of its application with respect to nota. The analogy of this juxtaposition to the double mental counterpart, imagines and cogitationes, is nevertheless striking.

There is no evidence that Melanchthon's theory of language came close to naturalism as presented by Cratylos in the famous dialogue by Plato, and thus shifted from the Aristotelian tradition, which Ian Maclean identified as a proper Renaissance paradigm, to the Platonic one. ${ }^{156}$ So it is necessary to find a different solution that would allow one to comprehend the Janus nature 
that characterized the notion of the conventionality of sign and to discover its second, "iconic bottom."

The way in which Melanchthon understood the conventionality of sign was derivative of his conception of language, which I characterized above. In this respect, he was by no means original. As Demonet rightly notices, Renaissance humanists - being Aristotelians in linguistics - considered sign as motivated by and not subject to the caprice of any individual decision. ${ }^{157}$ Thus it is clear that for Melanchthon, radical conventionalism in the mould of (for example) Robert Fland ${ }^{158}$ would be unacceptable because it was a wholly arbitrary choice that could determine signification in this approach. Only an ahistoric attitude towards language, typical for scholastics, could be the foundation of such a solution (rather rare, after all), whereas for Melanchthon language was an essential bond of a concrete historical community that was, additionally, the medium of the Revelation of God-Orator. The reconstruction of this backdrop elucidates that words understood as conventional signs had to play the role of pictures in the metaphorical sense. The shape of language as naturally formed put language itself in the way of reflecting the structure of reality in a somewhat derivative manner. It should be pointed out that if we set this approach against Ammonios's attempts to reconcile Plato and Aristotle, it will betray a slightly Neo-Platonist flavour. While referring to Plato's dialogue, Ammonios rejected both radical naturalism as presented by Cratylos-who like Heraclites believed that words bore similarity to natural images of the visible things - and conventionalism as defended by Hermogenes, according to whom one could name things as he pleased. ${ }^{159}$ In Ammonios's estimation, the moderate variants of these conceptions seemed decidedly more convincing. While characterizing the second physei-conception he expanded on an iconic analogy. I will quote this passage in Greek to trace terminological shifts:

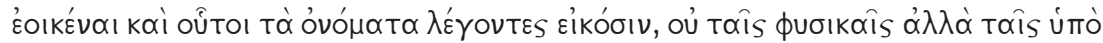

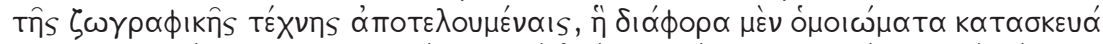

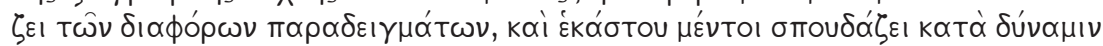

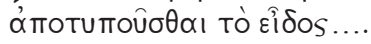

eoikenai kai houtoi ta onomata legontes eikosin, ou tais physikais alla tais hypo tês zôgraphikês technês apoteloumenais, hê diaphora men homoiômata kataskeuazei tôn diaphorôn paradeigmatôn, kai hekastou mentoi spoudazei kata dynamin apotypousthai to eidos.... 160

The difference between the two naturalist approaches lies in the character of images to which words are similar. While according to the radical approach they are natural, in the moderate variant they gain the capacity to represent 
things as do paintings. It is worth noting here that in this passage Ammonios employed the term ó $\mu$ oi $\omega \mu \alpha$, connoting representativeness. There is a striking similarity between this metaphor and that of Melanchthon, mentioned above. It does not follow, however, that Melanchthon was a naturalist in linguistics, for the second physei-conception did not differ considerably from the second thesei-conception positing that the language-producing soul intended to create names with a view to the real nature of each thing. This tendency was, as already stated, present also in Galen's works. As Ammonios put this, "the second physei-conception concurs with the second thesei-conception because the names given as fitting to the things by the name-giver are called 'physei,' but when they are given by anybody, thesei." Ammonios himself was nevertheless more radical than Galen and Melanchthon. According to him, Aristotle negated the naturalness of names only in the Heraclitean sense; he did not object to calling them physei in the same sense as the divine Plato did. ${ }^{161}$

So we can conclude that in Melanchthon words are to be interpreted as picturae, not with regard to the conventionality of their significance, but with regard to their motivation, which was also founded theologically in the sense that Melanchthon viewed speech as the picture (effigies) of thought, analogical to $\lambda$ óyos - the image of God the Father (they differed, however, in the nature of resemblance: as a person, God the Son was, of course, a substantial image). ${ }^{162}$ Thus, the above characterized correlation of notitiae with divine verbum also embodies words as their linguistic expression. What is more, the juxtaposition notae-picturae from Liber de anima seems to be a logical complement to picturesque comparisons and metaphors concerning the affinity of speech and painting (e.g. vultus sententiarum from the quoted passage of Encomion eloquentiae) at the most basic linguistic level, which proves Melanchthon's consistency in burdening language with the function of the fundamental instrument of cognition. ${ }^{163}$ These observations can shed light on a remarkable analogy, mentioned above: notae et picturae at the linguistic level and cogitationes et imagines with respect to the operations of intellect.

The role of this analogy cannot be reduced to that of a mere rhetorical ornament: it would be inconsistent with the way in which Melanchthon understood the rudiments of rhetoric as translatable into the categories of dialectic. Let us therefore elucidate it on an epistemological plane. It is significant that the symmetrical correspondence of the mental and linguistic components of an Aristotelian-like triad shows vividly their epistemological isomorphism. As opposed to isomorphism in Aristotle's theory of language, ${ }^{164}$ it is language that is focused on: words are not only signs - as 
such they could turn out to be deceptive - but also natural pictures. This isomorphism is, of course, wholly conditioned by the transitive notion of linguistic sign that was taken for granted by Melanchthon. Linguistic sign makes one think of notion, and notion puts to mind the thing itself. ${ }^{165}$ Thus the analogy presented reflects epistemological isomorphism with dialectical precision and not metaphorically. This hypothesis finds confirmation in the fact that in the light of research conducted from two wholly different points of view - theological and linguistic one - notions and words can be regarded as isomorphic as far as their creative function in the process of cognition is concerned. Let us quote a remarkable statement about notions from a book by Günter Frank: "Erkenntnis ist die schöpferische Konzeptualisierung aus der Perspektive des menschlichen Geistes aufgrund der ihm eingestifteten ,notitiae naturales"."166 We can find similar reflections on the role of Latin language in humanists' works in Ann Moss: “'Things' came to mind because words produced them, and the perception of 'things' was at least nuanced by the words.... At the very least, some measure of reversal became feasible in the one-way direction implicit in Aristotle's move from external objects to mental events to words.... Words, after all, remained arbiters of truth."167

The conclusions cited above were formulated with the aid of a wholly different methodology. As a result, each of them elucidates only one side of the problem. However, if they are studied with respect to the analogy under consideration, it is possible to gain a synthesis that can shed light on supposed contradictions in Melanchthon's system. Melanchthon often resorts to notions; at the same time, he underlines the indispensability of the linguistic medium. To take some examples: Notitiae innatae as the mental grains of $\operatorname{arts}^{168}$ do not seem to harmonize with orbis doctrinarum necessarily mediated by language. Similarly, some relations can be grasped only mentally for want of a word expressing the relation given, so they are not always of a linguistic nature. ${ }^{169}$ However, within the frames of the carefully reconstructed Melanchthonian model, the primacy of language in epistemology does not exclude notions as non-existing abstracts or deny their creativeness in cognition. It is only a point of reference, somewhat empirical as naturally formed, that allows one to verify cognition and to enlarge his set of notions - almost unchangeable for scholastics ${ }^{170}$ — by including ideas passed on through the classical literary tradition. The function of language results from the weakening of cognitive powers, described above. The effect of its employment was the demolition of speculative metaphysics, which Frank calls the deontologization of the notion of reality. ${ }^{171}$ Frank's conclusions in this matter, however, must be complemented by the statement that, in a broader perspec- 
tive, Melanchthon laid the foundations of the ontology of language, because language began to determine the horizons of metaphysical reflection.

\section{Jagiellonian University, Cracow, Poland}

\section{Notes}

I would like to thank the anonymous readers of this journal for their excellent advice, Professor Ann Moss for her help in clarifying terms, and Dr Jacqueline Glomski, from whose suggestions my translations have benefited greatly.

1. Unless otherwise stated, all English translations are mine. The original text can be found in Philipp Melanchthon, Encomion eloquentiae, in Werke in Auswahl, vol. 3, Humanistische Schriften, ed. Richard Nürnberger and Robert Stupperich (Gütersloh: Bertelsmann, 1961), pp. 46-47, as follows: "Et quemadmodum in fingendis corporibus ea demum elegantia est, ubi iusta proportione membra omnia inter se consentiunt, si quid secus facias, monstrosum erit, ita cum germanam orationis speciem nova compositione deformaveris, monstrosam plane atque ineptam facies.... An vero recte corpus imitabitur pictor, si nulla ratione penicillum regat, si temere feratur manus nec ducantur arte lineae? Ad eum modum nec animi tui sententiam aliis ob oculos posueris, ni propriis et illustribus verbis, apta vocum compositione, iusto sententiarum ordine utare. Nam perinde atque corpora coloribus, animi sententiam oratione repraesentamus. Quare necesse est dicendo certam aliquam imaginem arte concipi, quae discernat inter se tanquam vultus sententiarum."

2. Philipp Melanchthon, Elementorum rhetorices libri duo, in Corpus Reformatorum. Philippi Melanthonis Opera quae supersunt omnia, vol. 13, ed. Karl Gottlieb Bretschneider (Halis Saxonum: Schwetschke, 1846; facsimile in Joachim Knape, Philipp Melanchthons "Rhetorik" [Tübingen: Max Niemeyer Verlag, 1993]), col. 504:

"Plurimum etiam conducit ad iudicandum, agnoscere diversa genera dicendi. Nam ingeniorum dissimilitudo, diversas formas ..., non solum in hac arte, sed in plaerisque aliis peperit. Et tamen certi quasi gradus animadversi sunt, intra quos hae formae consistunt, videlicet humile genus, et ille oppositum grande. Tertium est mediocre, quod primo genere plenius est, et tamen aliquantulum a summo abest, in picturis facile deprehendi hae differentiae possunt. Durerus enim pingebat omnia grandiora, et frequentissimis lineis variata. Lucae picturae graciles sunt, quae et si blandae sunt, tamen quantum distent a Dureri operibus, collatio ostendit. Matthias quasi mediocritatem servabat."

("It is also very useful, in forming a judgment, to distinguish the various styles of speaking, for the variation in personal talents has given rise, in speaking as in many other arts, to various types of works,... And yet certain gradations, so to speak, have been distinguished, within which these types are contained: there is the Simple style, and its opposite the grand. The third is the Middle, which is fuller than the first, but yet lacks something of the Grand style. These differences may be readily discerned in paintings. For example, Dürer painted everything in the Grand manner, variegated with innumerable lines. The paintings of Lucas are Simple; although they are charming, a comparison will show how far removed they are from the works of Dürer. Matthias remained more or less in the Middle style." [trans. George Houston, quoted in Donald B. Kuspit, "Melanchthon and Dürer: the Search for the Simple Style," Journal of Medieval and Renaissance Studies 3 (1973), p. 185]) 
3. Wilhelm Schmidt-Biggemann, Topica universalis: eine Modellgeschichte humanistischer und barocker Wissenschaft, Paradeigmata, vol. 1 (Hamburg: Meiner, 1983), pp. 19-21.

4. Kees Meerhoff, "Logique et création selon Melanchthon. À la recherche du lieu commun," Entre logique et littérature: autour de Philippe Melanchthon (Orléans: Paradigme, 2001), pp. 72-73. See Philipp Melanchthon, Compendiaria dialectices ratio, in Opera omnia, vol. 20, ed. Heinrich Ernst Bindseil (Brunswick: Schwetschke, 1854), col. 759: "Usus est earum [caussarum efficientium] et in rhetoricis thematis, ut in laudibus ducuntur argumenta honestatis a conditoribus et autoribus rerum, ut, quae prior laus est matrimonii, quam quod divinitus constitutum est?"

("They [the efficient causes] are useful also in rhetorical subjects, like in praises, arguments for honesty can be built on founders and creators of things as which praise of matrimony precedes that it is established from heaven?")

5. Meerhoff, "Logique et création selon Melanchthon," pp. 74, 75.

6. Paolo Rossi, "Mnemonical and Natural Loci," Persuading Science: the Art of Scientific Rhetoric, ed. Marcello Pera and William R. Shea (Canton, Mass.: Science History Publications, USA, 1991), pp. 79, 83, 79-80.

7. Antoine Arnauld and Pierre Nicole, La logique ou l'art de penser, ed. Pierre Clair and François Girbal (Paris: Presses Universitaires de France, 1965), pp. 232-236 : “...rien ne rend un esprit plus stérile en pensées justes \& solides, que cette mauvaise fertilité de pensées communes." (p. 235). See Ann Moss, Printed Commonplace-Books and the Structuring of Renaissance Thought (Oxford: Clarendon Press, 1996), pp. 266-268.

8. "Necessitas historiae naturalis Rossiae, quam Praeside C. Linnaeo, proposuit Alexander de Karamyschew, Upsaliae, 1766, maij, 15," in Ch. Linné, Amoenitates Academicae (Holmiae, 1769), VII, p. 439, quoted in Rossi, p. 80.

9. Melanchthon, Elementorum rhetorices libri duo, col. 479-480, 490.

10. Melanchthon, Erotemata dialectices, in Opera omnia, vol. 13, col. 627.

11. Rodolphus Agricola, De inventione dialectica libri tres. Drei Bücher über die Inventio dialectica (Tübingen: Niemeyer, 1992), pp. 152-164. See Peter Mack, Renaissance Argument: Valla and Agricola in the Traditions of Rhetoric and Dialectic (Leiden: Brill, 1993), pp. 149, 161-165.

12. Melanchthon, Compendiaria dialectices ratio, col. 750, 746-47, 762-63.

13. Philipp Melanchthon, De dialectica libri quatuor (Lipsiae: Nicolaus Faber, 1536), lib. IV: de locis argumentorum, locus ex similitudine: "Infirma enim argumenta inde ducuntur,... Quare uulgo Dialecticis in ore est haec sententia, Omnis similitudo caudicat. Saepe tamen quia delectat collatio tanquam quaedam rei pictura incurrens in oculos, magnam vim habet."

14. Agricola, De inventione dialectica libri tres, pp. 196-199. See Eleonore Stump, "Consequences and the Decline of Aristotelianism," Dialectic and Its Place in the Development of Medieval Logic (Ithaca, NY: Cornell University Press, 1989), p. 161. For the usefulness of the loci extrinseci, among other things locus a similibus in the earlier scholastic tradition, see N. J. Green-Pedersen, "On the Interpretation of Aristotle's Topics in the Thirteenth Century," Cahiers de l'Institut de Moyen-Age Grec et Latin 9 (1973), pp. 2123.

15. Agricola, De inventione dialectica libri tres, p. 20: 
94/ Renaissance and Reformation / Renaissance et Réforme

"Sed cupio explicare ista meae turbae, id est, crassioribus atque harum rerum imperitis, quando doctis quidem supervacuus est praeceptor. Vellem itaque me non dicere modo ista, sed vel pingere, si res id caperet, vel sculpere etiam posse, et tum quoque pulchre mecum agi putarem, si non sic etiam mihi soli ista viderer elaborasse, sed aliquibus profuturus labor meus aliquorum esset studia iuvaturus."

English translation: Peter Mack, in Mack, "Agricola's Use of the Comparison between Writing and the Visual Arts," Journal of the Warburg and Courtauld Institutes 55 (1992), p. 171.

16. Ann Moss, Renaissance Truth and the Latin Language Turn (Oxford: Oxford University Press, 2003), pp. 165-67. See Kees Meerhoff, "Melanchthon lecteur d'Agricola. Rhétorique et analyse textuelle," Entre logique et littérature: autour de Philippe Melanchthon, pp. 27-28.

17. Michael Baxandall, "Rudolf Agricola and the Visual Arts," Intuition und Kunstwissenschaft: Festschrift für Hanns Swarzenski zum 70, Geburtstag, ed. Hanns Swarzenski and Peter Bloch (Berlin: Mann, 1973), pp. 410, 416; Mack, "Agricola's Use of the Comparison between Writing and the Visual Arts," p. 171.

Walter J. Ong, Ramus, Method, and the Decay of Dialogue: from the Art of Discourse to the Art of Reason (Cambridge, Mass.: Harvard University Press, 1958), pp. 104-112. However, Ong's thesis on the reduction of an auditory approach in Agricola needs revision in light of recent research on Renaissance linguistics.

18. Melanchthon, Erotemata dialectices, col. 688.

19. Philipp Melanchthon, De locis communibus ratio, in Opera omnia, vol. 20, col. 695698.

"Philosophi digesserunt res humanas omnes ceu in formas quasdam vivendi, ut alia sunt naturae, ut vita, mors, forma; alia fortunae, ut opes, natalium splendor, honores. Alia sunt in nostra potestate, ut vitia ac virtutes. Sic et in singulis studiorum generibus sunt quaedam capita, in quae referri solent, quae tractantur illic, ut in Theologia, fides, ceremonia, peccatum; in iure aequitas, servitus.... Qui volet igitur de rebus humanis recte iudicare, illum oportet, quicquid inciderit forte fortuna, ad has ceu formas rerum exigere. Pariter, cui cordi est recte de studiis iudicare, illum oportet tales locos in numerato habere. Nam praeter id, quod sunt formae rerum et regulae, mire etiam memoriam adiuvant." (col. 695)

("Philosophers divided all human things so to say into certain patterns of life. Just as some belong to nature, for example, life, death, appearance, others - to chance, for example, fortune, distinguished birth, public honors, others are in our power, for example, vices and virtues, so also are there certain headings in specific sorts of studies, to which their subject matter is usually referred, for example, in theology: faith, ceremony, sin; in law justice, servitude... Therefore anyone who wishes to judge human things correctly, must estimate everything that would happen by good luck by the standard of these, that is to say, patterns of things. Similarly, anyone who cares about judging studies correctly must have such Topics in readiness. For besides being patterns of things and rules, they also support memory wonderfully.")

See Moss, Printed Commonplace-Books, pp. 119-121.

20. Melanchthon, Erotemata, col. 641: "Haec ars [inventrix] vocatur topikh $\backslash$, id est, doctrina locorum, qui sunt velut indices rerum, vel investigandarum, vel eligendarum, ut Medicus 
proposito signo externo, ut velocitate, vel inaequalitate pulsus arteriae, sequitur locum $\mathrm{ab}$ effectu, scit signi huius quaerendam esse causam, hoc est, fontem pulsus, scilicet cor...."

In preparing my English translation (see main text) I have made use of the translation by Quirinus Breen: Breen, “The Terms 'Loci Communes' and 'Loci' in Melanchthon," Church History 16/4 (Dec., 1947), p. 205.

21. Günter Frank, Die theologische Philosophie Philipp Melanchthons: (1497-1560), Erfurter theologische Studien, vol. 67 (Hildesheim: Verlagsgesellschaft Benno-BernwardMorus, 1995), pp. 112, 116-117. See e.g. Philipp Melanchthon, Loci Commvnes Rervm Theologicarvm Sev Hypotyposes Theologicae (Wittenberg: Melchior Lotter der Jüngere, 1521), E ij.

22. Melanchthon, Erotemata, col. 647-650; idem, Liber de anima, in Opera omnia, vol. 13, col. 150.

23. Melanchthon, Elementorum rhetorices libri duo, col. 464.

24. Melanchthon, Erotemata, col. 563.

25. Melanchthon, Erotemata, col. 694: "saepius affirmative valet consequentia a simili, cum fit collatio earum partium quae congruunt."

26. Melanchthon, Erotemata, col. 694:

In pictura summum decus est, rectissime imitari naturales figuras corporum,

Ergo et in eloquentia summum decus est,

res vere cogitatas oratione propria exponere.

An obvious analogy to a famous expression of aesthetic criticism "as is painting, so is poetry" (Horace De Arte Poetica liber 361) is to be noted here. See also Agricola, De inventione dialectica, p. 216: "Erudite itaque Plutarchus inquit, poëma picturam loquentem esse, picturam esse tacens poëma, illud significans, docere ambas, et persaepe res easdem, sed alteram loqui, id quod altera ostendat." ("So Plutarch spoke perceptively when he said that a poem is a speaking picture and a picture a silent poem, meaning that both teach, and what they teach is often the same: but one states what the other shows." [trans. Peter Mack in Mack, "Agricola's Use of the Comparison between Writing and the Visual Arts," p. 173])

Plutarch De audiendis poetis 3: zôgraphian men einai phthengomenên tên poiêsin, poiêsin

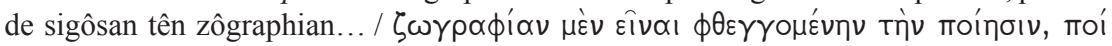

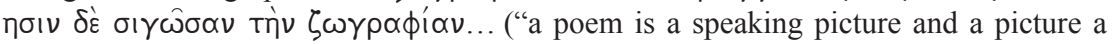
silent poem")

27. Melanchthon, Erotemata, col. 694.

28. See Sachiko Kusukawa, The Transformation of Natural Philosophy: the Case of Philip Melanchthon (Cambridge: Cambridge University Press, 1995), pp. 201-210.

29. Melanchthon, Erotemata, col. 715: "ut bonus pictor inspicit ideam cervi, et cum vidit monstrosam imaginem cervi ab ea discrepare, iudicat vitiosam esse."

30. Erwin Panofsky, Idea: A Concept in Art Theory, trans. Joseph J. S. Peake (Columbia: University of South Carolina Press, 1968), pp. 6-7, 181-182.

31. Marie-Luce Demonet, Les voix du signe: nature et origine du langage à la Renaissance (1480-1580) (Paris: Champion and Slatkine, 1992), p. 88. For an earlier history of De 
96/ Renaissance and Reformation / Renaissance et Réforme

interpretatione see Jean Isaac, Le peri hermeneias en Occident de Boèce à Saint Thomas: histoire littéraire d'un traité d'Aristote (Paris: Vrin, 1953).

32. For example: Demonet; Moss, Renaissance truth and the Latin language turn; Siegfried Wiedenhofer, "Theologie und Sprache," in Formalstrukturen humanistischer und reformatorischer Theologie bei Philipp Melanchthon, pt. 1 (Bern, Frankfurt/M.: H. Lang, P. Lang, 1976), pp. 430-71.

33. Aristotle On Interpretation (trans. H. P. Cook in The Categories. On Interpretation. Prior Analytics [London: Heinemann; Cambridge, Mass.: Harvard University Press, 1962]) 16 a.

34. Aristotle On the Soul (trans. W. S. Hett in On the Soul. Parva naturalia. On Breath, rev. and reprint ed. [Cambridge, Mass.: Harvard University Press, 1957]) 432a.

35. John L. Ackrill, Aristotle's Categories and De Interpretatione (Oxford: Clarendon Press, 1963), p. 113.

36. Norman Kretzmann, "Aristotle on Spoken Sound Significant by Convention," Ancient Logic and Its Modern Interpretations, ed. John Corcoran (Dordrecht: Reidel, 1974), p. 4.

37. Aristotle De interpretatione, 16a16-19, 16a8-9.

38. See Kretzmann, pp. 10-11; Ronald Polansky and Mark Kuczewski, "Speech and Thought, Symbol and Likeness: Aristotle's De Interpretatione 16a3-9," Apeiron: a Journal for Ancient Philosophy and Science 23/1 (1990), p. 53, note 9.

39. See Ackrill, pp. 113-14.

40. Lambert Marie de Rijk, "On Ancient and Medieval Semantics and Metaphysics," Vivarium 15/2 (1977), pp. 84-85.

41. Kretzmann, p. 11.

42. Polansky and Kuczewski. Page numbers will appear in parentheses in the main text.

43. Travis Butler, "On David Charles's Account of Aristotle's Semantics for Simple Names," Phronesis: A Journal for Ancient Philosophy 42/1 (1997), pp. 20-31. Polansky and Kuczewski made reference to an earlier version of Charles's ideas discussed by Butler: David Charles, "Aristotle on Meaning and Natural Kinds," paper read at a 1986 meeting of the Society for Ancient Greek Philosophy. See Polansky and Kuczewski, p. 54, note 10. See David Charles, “Aristotle on Names and Their Signification," in Language, ed. Stephen Everson, Companions to Ancient Thought, vol. 3 (Cambridge: Cambridge University Press, 1994), p. 73.

44. Charles, "Aristotle on Names and Their Signification," p. 42.

45. Butler, p. 23.

46. Charles, "Aristotle on Names and Their Signification," pp. 45, 72.

47. Butler, p. 30.

48. Aristotle De anima 407b.

49. Butler, pp. 27-28; 30-31. See Aristotle De anima 403b22; De interpretatione 17a20ff.

50. Lambert Marie de Rijk, Aristotle: Semantics and Ontology, vol. 1, General Introduction. The works on Logic (Leiden: Brill, 2002), pp. 20-23. 
51. Deborah K.W. Modrak, Aristotle's Theory of Language and Meaning (Cambridge: Cambridge University Press, 2001).

52. Melanchthon, Liber de anima, col. 143.

53. Melanchthon, Erotemata, col. 535-38.

54. Following Galen, Melanchthon distinguishes three internal senses: sensus communis, cogitatio seu compositio, and memoria.

55. Melanchthon, Liber de anima, col. 145; Erotemata, col. 519, 611.

56. Verzeichnis der Vorlesungen Melanchthons in Karl Hartfelder, Melanchthon als Praeceptor Germaniae (Berlin, 1889), p. 558.

Kees Meerhoff, "The Significance of Philip Melanchthon's Rhetoric in the Renaissance," Renaissance Rhetoric, ed. Peter Mack (New York, N.Y.: St. Martin, 1994), p. 50.

57. Perhaps Lucas Cranach the Elder, but it is not clear whether Melanchthon meant the son or the father. See Melanchthon, Erotemata, col. 535.

58. Melanchthon, Liber de anima, col. 145-146.

59. Melanchthon, Erotemata, col. 535: "Linea est longitudo sine latitudine et profunditate, cuius extrema sunt duo puncta. Sciant autem iuniores, non dici hic de linea picta, sed mente cogitanda est sola longitudo abstracta a corporibus."

See Aristotle De memoria et reminiscentia 450a.

60. I wish to thank Professor Ann Moss for her help in clarifying "exemplarism." See Melanchthon, Declamatio de partibus et motibus cordis, in Opera omnia, vol. 11, ed. Carolus Gottlieb Bretschneider (Halis Saxonum: Schwetschke, 1843), col. 948 :

"Vult nos Deus exordia huius sapientiae in hac vita discere, postea intuentes ipsam naturae ideam in mente divina, non solum perspiciemus rerum substantias, sed etiam consilia Dei cognoscemus, quid cor ita condere rectius fuerit."

("God wishes that we knew the rudiments of this wisdom in this life, afterwards while contemplating the idea of nature itself in the divine thought, not only will we cognize the substances of things but also we will know the plans of God.")

61. Melanchthon, Liber de anima, col. 143-144.

62. Augustine, De Trinitate 6.2.3: "non autem pater et filius simul ambo imago, sed filius solus imago patris quemadmodum et filius;") "but the Father and Son are not both together the Image, but the Son alone is the Image of the Father: just as He is also the Son of the Father,..." [trans. Arthur West Haddan]). See Hans Arens, "“Verbum cordis.' Zur Sprachphilosophie des Mittelalters," Historiographia Linguistica 7, no.1/2 (1980), pp. 17-18.

63. For the typically Protestant identification of notions imago Dei (the anthropological structure of man) and similitudo (the losable Christ-likeness) and their relationship to notitiae innatae in Melanchthon, see Frank, pp. 102-111.

64. Melanchthon, Liber de anima, col. 145: "Mirando autem consilio Deus noticias voluit esse imagines, quia in nobis umbras esse voluit significantes aliquid de ipso. Aeternus pater sese intuens gignit filium cogitando, qui est imago aeterni patris."

65. Melanchthon, Liber de anima, col. 143.

66. Modrak, pp. 259-62. 
67. Philipp Melanchthon, Initia doctrinae physicae, in Opera omnia, vol. 13, col. 181, 191, 198-199, 213, 291; Liber de anima, col. 69, 121, 144.

68. Peter Harrison, "Original Sin and the Problem of Knowledge in Early Modern Europe," Journal of the History of Ideas 63/2 (April 2002), pp. 241-43.

69. Melanchthon, Liber de anima, col. 144.

70. Wiedenhofer, Formalstrukturen, pt. 1, pp. 448-50.

71. Translation by Erwin Panofsky, p. 6 of Idea, from Philipp Melanchthon, Enarratio libri I. Ethicorum Aristotelis in Opera omnia, vol. 16, ed. Heinrich Ernst Bindseil (Halis Saxonum: Schwetschke, 1850), col. 290: "Certum est, Platonem ubique vocare Ideas perfectam et illustrem notitiam, ut Apelles habet in animo inclusam pulcherrimam imaginem humani corporis." References to Panofsky's Idea, in the coming section, will appear in the main text in parentheses.

72. Panofsky is quoting from Aristotle Metaphysics 1034a.

73. This can be traced back to the Kant's famous Copernican revolution, whose core was the assumption that man is incapable of getting to know things in themselves because objects of knowledge must conform to his noetic faculty.

74. Demonet, p. 393.

75. See Aristotle Metaphysics $1032 \mathrm{~b}$ :

"apo technês de gignetai hosôn to eidos en tê psychê; eidos de legô to ti ên einai hekastou kai tên prôtên ousian;"

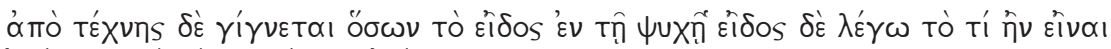

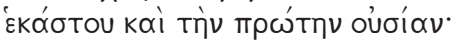

"Things are generated artificially whose form is contained in the soul (by "form" I mean the essence of each thing, and its primary substance)" (trans. Hugh Tredennick)

76. Aristotle On Interpretation (trans. H. P. Cook in The Categories. On Interpretation. Prior Analytics) 17a1-4.

77. See for example Jan Pinborg, Logik und Semantik im Mittelalter: ein Überblick, with an afterword by Helmut Kohlenberger (Stuttgart-Bad Cannstatt: Frommann-Holzboog, 1972), pp. 32-42. See Rijk, "On Ancient and Medieval Semantics and Metaphysics," p. 84; R. Gaskin, "Simplicius on the Meaning of Sentences: A Commentary on In Cat. 396, 30-397,28," Phronesis: A Journal for Ancient Philosophy 43/1 (1998), pp. 45-46, $60-62$.

78. Translation by Robert W. Mulligan, in St. Thomas Aquinas, Truth, trans. Robert W. Mulligan, James V. McGlynn and Robert W. Schmidt, vol. 1, Questions I-IX (Indianapolis: Hackett Pub. Co., 1994; originally published: H. Regnery Co., 1952-1954), p. 140.

Thomas Aquinas, De veritate, q. 3 a. 1 co.: "Tertio modo dicitur forma alicuius ad quam aliquid formatur; et haec est forma exemplaris, ad cuius imitationem aliquid constituitur; et in hac significatione consuetum est nomen ideae accipi, ut idem sit idea quod forma quam aliquid imitator."

79. Translation by Robert W. Mulligan, in St. Thomas Aquinas, Truth, vol. 1, p. 140.

Thomas Aquinas, De veritate, q. 3 a. 1 co.: "Dicimus enim formam artis in artifice esse exemplar vel ideam artificiati; et similiter etiam formam quae est extra artificem, ad cuius 
imitationem artifex aliquid facit. Haec ergo videtur esse ratio ideae, quod idea sit forma quam aliquid imitatur ex intentione agentis, qui praedeterminat sibi finem"

80. See Dominik Perler, "Things in the Mind. Fourteenth-Century Controversies over 'Intelligible Species'," Vivarium 34/2 (1996), p. 232.

81. Trans. Fathers of the English Dominican Province [or rather, by Laurence Shapcote], rev. Daniel J. Sullivan in The Summa Theologica, vol. 1 [Chicago: Encyclopaedia Britannica, 1952]). From Thomas Aquinas, Summa theologiae, I' q. 85 a. 2 ad 3: "Non ergo voces significant ipsas species intelligibiles; sed ea quae intellectus sibi format ad iudicandum de rebus exterioribus."

82. William of Ockham, Scriptum in librum primum sententiarum ordinatio. Distinctiones $X I X-X L V I I$, ed. Girardus I. Etzkorn et Franciscus E. Kelley, lib. I, dist. 35, q. V, in Opera philosophica et theologica. Opera theologica, vol. 4 (St. Bonaventure, N.Y.: St. Bonaventure University, 1979): "Quia non est nisi aliquid cognitum ad quod cognoscens aspicit in producendo, ut secundum ipsum aliquid simile illi vel ipsummet producat in esse reali. Sicut una domus potest vere dici idea et exemplar alterius domus, quia scilicet aliquis artifex illam domum cognoscendo, potest per hoc aliam consimilem fabricare. Et eodem modo, si ipsamet domus in particulari esset ab artifice praecognita et virtute illius posset domum illam eandem producere, ipsa domus esset exemplar et idea sui ipsius, ad quam artifex aspiciens posset ipsammet producere in esse reali."

83. Charles, "Aristotle on Names and Their Signification," p. 72.

84. Thomas Aquinas, De veritate, q. 3 a. 1 co.

85. See Ian Maclean, Logic, Signs and Nature in the Renaissance (Cambridge: Cambridge University Press, 2002 ), p. 128 ff.

86. Melanchthon, Scholia in Ciceronis Oratorem, in Opera omnia, vol. 16, col. 772: "Hanc absolutam et perfectam rei definitionem Plato vocat Ideam...." ("Plato calls this absolute and perfect definition of a thing Idea...").

87. Melanchthon, Declamatio contra emipircos medicos, in Opera omnia, vol. 11, ed. Carolus Gottlieb Bretschneider (Halis Saxonum: Schwetschke, 1843), col. 203.

88. Melanchthon, Enarratio libri X. Institutionum Oratoriarum Quintiliani, in Opera omnia, vol. 17, ed. Heinrich Ernst Bindseil (Halis Saxonum: Schwetschke, 1851), col. 678: "Cum verto aliquam orationem Demosthenis, oportet me animo concipere quandam ideam istius reipublicae, et videor mihi coram cernere formam reipublicae Athenienis, atque in ea versari. Haec ipsa cogitatio multum prodest in omni vita."

89. Claude Panaccio, Les mots, les concepts et les choses: la sémantique de Guillaume d'Occam et le nominalisme d'aujourd'hui (Montréal: Bellarmin, 1992), pp. 82-86. See Lodi Nauta, "William of Ockham and Lorenzo Valla: False Friends. Semantics and Ontological Reduction,” Renaissance Quarterly 56/3 (2003), pp. 613-51.

90. Christopher S. Celenza, "Lorenzo Valla and the Traditions and Transmissions of Philosophy," Journal of the History of Ideas 66/4 (October 2005), pp. 483-506.

91. Gérard Verbeke, introduction to Ammonius, Commentaire sur le Peri hermeneias d'Aristote. Traduction de Guillaume de Moerbeke, ed. Gérard Verbeke, Corpus latinum commentariorum in Aristotelem graecorum, vol. 2 (Louvain, 1961), p. i. 
100/ Renaissance and Reformation / Renaissance et Réforme

92. Richard J. Durling, “A Chronological Census of Renaissance Editions and Translations of Galen," Journal of the Warburg and Courtauld Institutes 24/3-4 (Jul-Dec. 1961), pp. 230-305.

93. Melanchthon, De physica, in Opera omnia, vol. 11, col. 556-557.

94. Melanchthon, De vita Galeni, in Opera omnia, vol. 11, col. 499-500.

95. Galen, De Hippocratis et Platonis decretis in Opera omnia, ed. Karl Gottlob Kühn, vol. 5 (Leipzig: Car. Cnoblochii, 1821-1833), pp. 213-218.

96. Translation by Philip de Lacy, in Galen, On the Doctrines of Hippocrates and Plato, ed., trans. and commentary by Philip de Lacy, Second Part: Books VI-IX (Berlin: AkademieVerlag, 1984), p. 545.

Galen, De Hippocratis et Platonis decretis in Opera omnia, pp. 724-25:

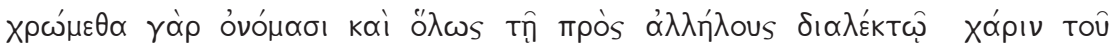

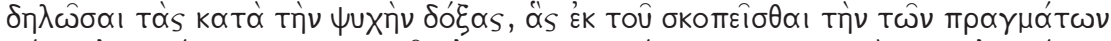

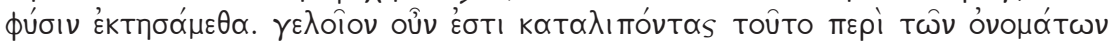
$\dot{\alpha} \mu \iota \lambda \lambda \hat{\alpha} \sigma \theta \alpha$ เ.

chrômetha gar onomasi kai holôs tê pros allêlous dialektô charin tou dêlôsai tas kata tên psychên doksas, has ek tou skopeisthai tên tôn pragmatôn physin ektêsametha. geloion oun esti katalipontas touto peri tôn onomatôn hamillasthai.

97. R.J. Hankinson, "Usage and Abusage: Galen on Language," Language, ed. Stephen Everson, pp. 167-171.

98. See Juan Luis Vives, De tradendis disciplinis, in Opera omnia, vol. 6 (Valentiae Edetanorum, 1785; reprint, London: Gregg, 1964), p. 353.

99. See Galenus, Über die medizinischen Namen, ed. Max Meyerhof and Joseph Schacht (Berlin: Verlag der Akademie der Wissenschaften, 1931).

100. Hankinson, pp. 170, 175. See Véronique Boudon, "Galien de Pergame," in Dictionnaire des philosophes antiques, ed. Richard Goulet, vol. 3 (Paris: Éditions du Centre national de la recherche scientifique, 2000), pp. 459, 462-63.

101. Ammonius, In Aristotelis De Interpretatione commentarius, ed. Adolf Busse, Commentaria in Aristotelem Graeca. vol.4, pt. 5 (Berlin: Georg Reimer, 1897), pp. 5-7.

102. Anicius Manlius Severinus Boetius, Commentarii in librum Aristotelis Peri Hermeneias, ed. Karl Meiser, pars posterior, secunda editio (Leipzig: Teubner, 1880), pp. 27-28.

103. Ammonios Hermeiu, "Commentary to Aristotle's Peri hermeneias," Aristotle's Theory of Language and Its Tradition: Texts from 500 to 1750, selection, translation and commentary by Hans Arens (Amsterdam: Benjamins, 1984), pp. 74-75.

104. Hermeiu, p. 94. See Ammonius, p. 38.

105. Hermeiu, p. 94.

106. Hans Arens, "Commentary to Ammonios," in Aristotle's Theory of Language and Its Tradition, pp. 137-38.

107. Walter Burley, De sensibus, ed. Herman Shapiro and Frederick Scott, Mitteilungen des Grabmann-Instituts der Universität München 13 (Munich: Hüber, 1966), p. 5 : “Intellectus dicitur ymaginativa propter similitudinem operationum unius et alterius, quia semper concurrunt in operationibus suis, quia, nihil intelligit sine fantasmate sive ymaginativa." 
108. Robert Holkot, Quaestiones quodlibetales, in William J. Courtenay, “A Revised Text of Robert Holcot's Quodlibetal Dispute on Whether God is Able to Know More Than He Knows," Archiv für Geschichte der Philosophie 53 (1971), pp. 16-17, 19.

"Et hoc est quod dicit, primo Perihermenias, ubi vult quod similitudines rerum, quae aliquando vocantur conceptus vel species, vel imagines, vel idola, aliquando intellectus, aliquando intentiones, aliquando verba mentalia, aliquando cognitiones, aliquando intellectiones, aliquando passiones animae, "tales inquam sunt eaedem apud omnes," id est aequivalentes in significando vel in repraesentando, "quia etiam res sunt eaedem apud omnes;" quia tales similitudines causantur a rebus et non significant ad placitum, sed naturaliter, res quarum sunt similitudines." (16-17).

"Conceptus vero aliquando est species, quando est repraesentativa rei extra, aliquando non.” (19).

Cf. an older edition: Ernest A. Moody, "A Quodlibetal Question of Robert Holkot, O.P. On the Problem of the Objects of Knowledge and of Belief," Speculum 39/1 (1964), pp. 53-74.

109. Olaf Pluta, Die philosophische Psychologie des Peter von Ailly, Bochumer Studien zur Philosophie, vol. 6 (Amsterdam: Grüner, 1987), pp. 1-2.

110. Peter von Ailly, Tractatus de anima, in Olaf Pluta, Die philosophische Psychologie des Peter von Ailly, pp. 45-46: "In primis autem sciendum est, quod, licet hoc nomen 'species' multipliciter sit aequivocum, tamen adhuc, ut pertinet ad materiam de notitiis, de qua tractamus, quadrupliciter solet capi... Tertio modo "pro omni forma, quae est similitudo et imago rei cognitae, et per quam res illa cognoscitur", et sic ipsa actualis notitia quandoque dicitur species."

111. Melanchthon, Erotemata, col. 611.

112. Rijk, Aristotle: Semantics and Ontology, vol. 1, pp. 16-20.

113. Julius Caesar Scaliger, De causis linguae latinae libri tredecim (Lugduni, apud Seb. Gryphium, 1540), p. 113: "Sicut in speculo ea, quae uidentur, non sunt, sed eorum species, unde etiam nomen obtinuere, ut Species appellarentur...: ita quae intelligimus, ea sunt re ipsa extra nos, eorumque species in nobis. Est enim quasi rerum speculum intellectus noster, cui nisi per sensum repraesententur res, nihil scit ipse."

114. Kristian Jensen, Rhetorical Philosophy and Philosophical Grammar: Julius Caesar Scaliger's Theory of Language (Munich: Fink, 1990), pp. 143, 146-147.

115. Demonet, p. 393.

116. Demonet, p. 390.

117. Katharine Park, “Albert's Influence on Late Medieval Psychology," Albertus Magnus and the Sciences, ed. James A. Weisheipl (Toronto: Pontifical Institute of Mediaeval Studies, 1980), pp. 529-30.

118. Stephan Meier-Oeser, Die Spur des Zeichens: das Zeichen und seine Funktion in der Philosophie des Mittelalters und der frühen Neuzeit (Berlin: de Gruyter, 1997), pp. 15758.

“... dicitur notitia similitudo obiecti, non quod habet similia lineamenta, sicut imago picta simili regis: sed dicitur intentionaliter similis, propterea quod suapte natura repraesentat obiectum." (Domingo de Soto, Summulae (1554) fol. 5va, quoted in Meier-Oeser, Die Spur des Zeichens, p. 158.) 
102/ Renaissance and Reformation / Renaissance et Réforme

"Notion is called the similitude of an object not because it has similar lineaments, like a painted image similar to a king, but it is called intentionally similar, for it represents an object through its nature."

119. Aristotle De interpretatione 24bI. See Demonet, p. 388.

120. Joachim Périon, Recensio ex editione Parisina, 1548, 16a5, in Aristoteles Latinus, vol. 2.1-2, De interpretatione: vel Periermenias, translatio Boethii; specimina translationum recentiorum edidit Laurentius Minio-Paluello; translatio Guillelmi de Moerbeke, edidit Gerardus Verbeke, revisit L. Minio-Paluello, Corpus philosophorum Medii Aevi (Bruges: Desclée de Brouwer, 1965), p. 100. Quoted as Aristoteles Latinus, vol. 2.1-2, p. 102.

121. Joachim Périon, "Annotationes in librum Aristotelis De interpretatione," in Porphyrii institutiones quinque vocum, Aristotelis categoriae; ejusdem De interpretatione liber, Joachimo Perionio Cormoeriaceno interprete, una cum ejusdem quoque annotationibus (Basileae: R. Winter, 1542), p. 151: "Nam et sensibus eadem omnia comprehenduntur, et ea quae mouens sensus, itidem mouent animum: quaeque in animis imprimuntur, de quibus ante dixi, inchoatae intelligentiae, similiter in omnibus imprimuntur..." See Demonet, p. 388.

122. Earline Jennifer Ashworth, Language and Logic in the Post-Medieval Period (Dordrecht: Reidel, 1974), p. 7.

123. He simply sidestepped the Latin counterpart of o $\mu$ oí $\omega \mu \alpha$. See Thomas Bricot, Recensio paraphrastica: ex editione Parisina (Mittelhus), 1489, 16a1-16a18, in Aristoteles Latinus, vol. 2.1-2, 85.

124. See Neal W. Gilbert, Renaissance Concepts of Method (New York: Columbia University Press, 1960), p. 36.

125. Cf. Joachim Périon, Recensio ex editione Parisina, 1548, 16a5, in Aristoteles Latinus, vol. 2.1-2, p. 100: "at vero et sensa animi, quorum primum verba notae sunt, et res quarum sensus animi speciem gerunt, idem apud omnes valent."

Cf. Cicero De officiis 3.16: “... ex mediorum officiorum frequentia similitudinem quandam gerebant speciemque sapientium."

126. The hypothesis of Minio-Paluello, that Charpentier probably did not resort to the original text of On Interpretation, seems unjustified in the light of the research of Neal W. Gilbert. Besides, either he is mistaken in the name of Charpentier or a typographical error occurred (his name was, of course, Jacobus and not Joannes). See Gilbert, p. 147; Laurentius Minio-Paluello, introduction to Aristoteles Latinus, vol. 2.1-2, LXIX; Jacques Charpentier, Ad expositionem disputationis de methodo, contra Thessalum Ossatum, Academiae Parisiensis methodicum responsio (Parisiis: ex officina G. Buonii, 1564), p. 11.

127. Cicero De oratore 2.86. 353-354: "hac tum re admonitus invenisse fertur ordinem esse maxime, qui memoriae lumen adferret. [354] Itaque eis, qui hanc partem ingeni exercerent, locos esse capiendos et ea, quae memoria tenere vellent effingenda animo atque in eis locis conlocanda; sic fore, ut ordinem rerum locorum ordo conservaret, res autem ipsas rerum effigies notaret atque ut locis pro cera, simulacris pro litteris uteremur."

128. Cicero De divinatione 1.12.20: "sancta Iovis species claros spectaret in ortus...."

129. Rijk, Aristotle: Semantics and Ontology, vol. 1, pp. 20-23. 
130. Jacques Charpentier, Platonis cum Aristotele in universa philosophia comparatio, vol. 1 (Parisiis: ex officina Jacobi Du Puys, 1573), pp. 167, 45, 32. For a comparison of the translations by Périon and Charpentier, see Wilhelm Risse, Die Logik der Neuzeit, vol. 1, 1500-1640 (Stuttgart-Bad Cannstatt: Frommann-Holzboog, 1964), pp. 240-42.

131. A distinction between the meaning of a word by virtue of imposition and of representation was discussed in eleventh- and twelfth-century logic; it did not, however, relate to internal objects.

132. For this meaning of the notion of representation in Charpentier see Charpentier, Platonis cum Aristotele in universa philosophia comparatio, vol. 1, pp. 212, 213, 205, 206.

133. Cf. Philipp Melanchthon, Declamatio de cura recte loquendi, in Opera omnia, vol. 12 (Halis Saxonum: Schwetschke, 1844), col. 216, 220.

134. Albrecht Dürer, Schriftlicher Nachlass, vol. 1, ed. Hans Rupprich (Berlin: Deutscher Verein für Kunstwissenschaft, 1956), p. 289:

"Memini virum excellentem ingenio et virtute Albertum Durerum pictorem dicere, se iuvenem floridas et maxime varias picturas amasse, seque admiratorem suorum operum valde laetatum esse, contemplantem hanc varietatem in sua aliqua pictura. Postea se senem coepisse intueri naturam, et illius nativam faciem intueri conatum esse, eamque simplicitatem tunc intellexisse summum artis decus esse. Quam cum non prorsus adsequi posset, dicebat se iam non esse admiratorem operum suorum ut olim, sed saepe gemere intuentem suas tabulas, ac cogitantem de infirmitate sua. Tantum cum fuerit illius viri studium in arte non summa, saepe doleo et indignor, non esse similem diligentiam nostri ordinis in quaerenda simplicissima explicatione doctrinae coelestis."

The translation into English is by Donald B. Kuspit, quoted in Kuspit, pp. 188-89

135. Jan Białostocki, Dürer and his Critics, 1500-1971: Chapters in the History of Ideas Including a Collection of Texts (Baden-Baden: Koerner, 1986), p. 34.

136. Dürer, vol. 1, p. 289.

137. Kuspit, pp. 192-93.

138. Białostocki, p. 35.

139. Philipp Melanchthon, "Somnium Philippi de hyaena in comitiis Ratisbonensibus (1541)," in Opera omnia, vol. 10, ed. Karl Gottlieb Bretschneider (Halis Saxonum: Schwetschke, 1842), col. 576.

Philip's hyena dream during the Ratisbon Conference (1541):

Princes commanded me to paint a deceitful hyena,

And they set an image of the monster before my eyes.

It was a huge, sinister figure blended from variegated shapes,

And covered with livid bloody skin.

A virginal face, but gloomy eyes

Throwing flames showed dark signs of rage.

Limbs of twin Dragons hung from its neck

Finally at the lowest part were Scylla-like feet

I was terrified looking at it and the blood running along its whole body,

And as the flow of blood slowed, its life fled.

They insist however on me painting, but I do not obey, I angrily say

The feet cannot be painted well. 
104/ Renaissance and Reformation / Renaissance et Réforme

Where do you rush, Princes? What delusion occupies your minds?

Why do you carry such monsters in God's temple?

140. Heinz Scheible, "Melanchthons Auseinandersetzung mit dem Reformkatholizismus," Melanchthon und die Reformation: Forschungsbeiträge, ed. Gerhard May and Rolf Dewot (Mainz: von Zabern, 1996), p. 226.

141. See Oleg V. Bychkov, "The Reflection of Some Traditional Stoic Ideas in the ThirteenthCentury," Vivarium 34/2 (1996), pp. 148-51.

142. Melanchthon, Declamatio de amore veritatis, in Opera omnia, vol. 11, col. 269: "Videte quibus coloribus nunc ingeniosi homines pingant abusus ecclesiasticos, quibus technis veras sententias obruant. Quam multa inveniunt sofa $\backslash$ fa/rmaka, sopha pharmaka, ut medeantur absurdis opinionibus, quoties in eum locum ventum est, ubi oportet seu versare dolos, seu certae occumbere morti."

143. See e.g. Philipp Melanchthon, Pro Luthero apologia (Basel, Adam Petri, 1521).

144. Kuspit, pp. 193-94.

145. Scheible, pp. 238-41.

146. Melanchthon an den kaiserlichen Prediger [Gil Lopéz de Bejar] OFM in Scheible, p. 243: “...prodest modus loquendi, quod fides iustificet, quia facile intelligitur. Sensus fidei non est obscurus...".

147. Frank Büttner "“Argumentatio' in Bildern der Reformationszeit. Ein Beitrag zur Bestimmung argumentativer Strukturen in der Bildkunst," Zeitschrift für Kunstgeschichte 57 (1994), pp. 27-28.

148. Lucas Cranach the Elder, The Law and the Gospel, probably mixed media on lime wood, 1529, Schlossmuseum, Gotha, Germany.

149. Büttner, pp. 30-31.

150. For example: Jean Wirth, "Le dogme en images: Luther et l'iconographie," Revue de l'art 52 (1981), pp. 9-23. See also Friedrich Ohly, Gesetz und Evangelium: zur Typologie bei Luther und Lucas Cranach (Münster: Aschendorff, 1985).

151. Büttner, p. 33.

152. Melanchthon, Declamatio in laudem artis medicae, in Opera omnia, vol. 11, col. 197: "Non enim hic, ut in Pictura, inanes umbrae et vanae corporum imagines nos oblectant, sed res solidae et vivum naturae opus, et incredibile et varium eius decus, cum summa voluptate spectator...".

153. Demonet, pp. 164-65.

154. Melanchthon, Encomion eloquentiae, in Werke in Auswahl, vol. 3, p. 45: "Nam cum usu velut nummi vocabula probentur, receptis utendum est, quae quia eloquentes homines quasi per manus posteris tradidere, obscuritate vacant."

155. Melanchthon, Liber de anima, col. 65.

156. Ian Maclean, "Foucault's Renaissance Episteme Reassessed: An Aristotelian Counterblast," Journal of the History of Ideas 59/1 (January 1998), p. 155.

157. Demonet, p. 92.

158. See Paul Vincent Spade, "Robert Fland's Consequentiae: An Edition," Mediaeval Studies 38 (1976), pp. 54-84. 
159. Hermeiu, pp. 89-90.

160. Ammonius, In Aristotelis De Interpretatione commentarius, p. 35 :

"They too /sc. the other believers in 'physei'/ say that the names /or nouns or words/ are like pictures, not like the natural ones, but like those produced by the art of painting, which creates different pictures of the different exemplars and always tries, as well as it can, to represent the appearance of each" (trans. Hans Arens, in Aristotle's theory of language and its tradition, p. 90).

161. Hermeiu, pp. 90, 92, 93.

162. Philip Melanchthon, Enarratio in Evangelium Ioannis, in Opera omnia, vol. 15, ed. Carl Gottlieb Bretschneider (Halis Saxonum: Schwetschke, 1848), col. 9-11.

163. Note an interesting example of iconic motivation: "Ante laryngem positum est os bifurcatum, quod... basis est, cui alligata est Lingua per plurimos musculos. Galenus nominat

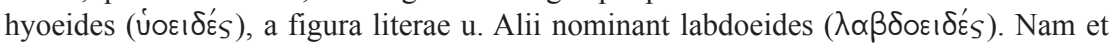
lambda $(\lambda \alpha \dot{\alpha} \mu \beta \delta \alpha)$ duos habet ramos" (Melanchthon, Liber de anima, col. 64).

164. See Eugene E. Ryan, Aristotle's Theory of Rhetorical Argumentation (Montreal: Bellarmin, 1984), pp. 158-59.

165. Were the Saussurian notion of sign as the unity of signified and signifier to be applied to the analogy under consideration, it would prove an artificial construction dividing elements that are unified in reality. In this context, the focus on language could entail the statement that it constitutes reality, and thinking as such is of a linguistic nature. The conclusions of that kind can, in fact, be encountered in research literature. They result from a more or less mechanical transfer of the notions of modern linguistics to ancient texts. See for example Richard Waswo, Language and Meaning in the Renaissance (Princeton, NJ: Princeton University Press, 1987) and the critique of his conception of referential semantics in Demonet and Monfasani. See Demonet, p. 11, n.17 and John Monfasani, "Was Lorenzo Valla an Ordinary Language Philosopher?" Journal of the History of Ideas 50/2 (Apr-June 1989), pp. 309-323. Regarding the confusion of rhetorical and linguistic planes, see: Olaf Berwald, Philipp Melanchthons Sicht der Rhetorik, Gratia, vol. 25 (Wiesbaden: Harrassowitz Verlag, 1994), p. 74.

166. Frank, p. 122. "Cognition is a creative conceptualisation from the perspective of the human mind by virtue of notitiae naturales given to him."

167. Moss, Renaissance truth and the Latin language turn, p. 90.

168. Melanchthon, Liber de anima, col. 144; idem, Erotemata, col. 647.

169. Melanchthon, Erotemata, col. 547.

170. Ashworth, p. 42. See also Jack Zupko, John Buridan: portrait of a fourteenth-century arts master (Notre Dame: University of Notre Dame Press, 2003), pp. 26-27.

171. Frank, p. 78. 